Board of Governors of the Federal Reserve System

International Finance Discussion Papers

Number 711

September 2001

\title{
THE CONTRIBUTION OF DOMESTIC AND EXTERNAL FACTORS TO EMERGING MARKET DEVALUATION CRISES: AN EARLY WARNING SYSTEMS APPROACH
}

\author{
Steven B. Kamin \\ John W. Schindler \\ Shawna L. Samuel
}

NOTE: International Finance Discussion Papers are preliminary materials circulated to stimulate discussion and critical comment. References in publications to International Finance Discussion Papers (other than an acknowledgment that the writer has had access to unpublished material) should be cleared with the author or authors. Recent IFDPs are available on the Web at www.federalreserve.gov/pubs/ifdp/. 


\title{
THE CONTRIBUTION OF DOMESTIC AND EXTERNAL FACTORS TO EMERGING MARKET DEVALUATION CRISES: AN EARLY WARNING SYSTEMS APPROACH
}

\author{
Steven B. Kamin* \\ John Schindler \\ Shawna Samuel
}

September 2001

\begin{abstract}
In this paper, a modified "early warning system" (EWS) approach is developed to identify the roles of domestic and external factors in emerging market crises. Several probit models of financial crises were estimated for 26 emerging market countries. These models were used to identify the separate contributions to the probabilities of crisis of domestic and external variables. We found that, relative to domestic factors, adverse external shocks and large external imbalances contributed little to the average estimated probability of crisis in emerging market countries, but accounted for much more of the spikes in the probability of crisis estimated to occur during actual crisis years. We interpret these results to suggest that while, on average over time, domestic factors have tended to contribute to much of the underlying vulnerability of emerging market countries, adverse swings in external factors may have been important in pushing economies "over the edge" and into financial crisis. In consequence, the costs of giving up exchange rate flexibility through adoption of strongly fixed exchange rate regimes-e.g., currency boards or dollarization-may be quite high for some countries.
\end{abstract}

Keywords: devaluations, financial crises, early warning systems, currency crises

*The authors are Assistant Director, Economist and Research Assistant, respectively, in the International Finance Division of the Federal Reserve Board. The first author can be reached at Mail Stop 23, Federal Reserve Board, Washington, DC 20551; steven.kamin@frb.gov. This paper is a revised and extended version of a previous draft-Steven B. Kamin and Oliver D. Babson, "The Contributions of Domestic and External Factors to Latin American Devaluation Crises: An Early Warning Systems Approach," September 1999-which focused solely on the Latin American economies. We would like to thank seminar participants in the International Finance Division, the Inter-American Development Bank, the American Economics Association meetings, the World Bank, and the Bank of Canada for very helpful comments on prior drafts. The views in this paper are solely the responsibility of the authors and should not be interpreted as reflecting the views of the Board of Governors of the Federal Reserve System or of any other person associated with the Federal Reserve System. 


\section{Introduction ${ }^{1}$}

The record of the emerging market financial crises in the 1990s-particularly in Mexico, developing Asia, Russia, and Brazil-has convinced many observers that the fixed but adjustable peg may be unsustainable and excessively vulnerable in a world of high capital mobility. An evolving, although not quite consensus, view holds that the most sustainable regimes are to be found at the far ends of the exchange rate regime spectrum: floating or highly flexible exchange rate systems, at one end, and much stronger commitments to fixed exchange rates-including currency boards or the adoption of a foreign currency ("dollarization")-at the other. However, considerable debate continues as to which of these extremes might best meet the needs of emerging market countries.

Clearly, many considerations bear on whether fixed or flexible exchange rates may be more appropriate for emerging market countries. ${ }^{2}$ One of these considerations is the source of financial crises in these economies. If, as some observers have suggested, emerging market crises primarily reflect domestic policy imbalances-for example, large fiscal deficits, rapid money creation, and excessive borrowing-then a credible, sustainable commitment to a fixed exchange rate against the dollar or other stable currency may, on net, be beneficial. The fixed exchange rate would narrow the scope for destabilizing monetary and fiscal policies, while not costing much in terms of the foregone ability to respond to adverse external shocks. Conversely, if emerging market financial problems importantly

\footnotetext{
${ }^{1}$ This paper extends the analysis described in a September 1999 working paper by Steven B. Kamin and Oliver D. Babson, "The Contributions of Domestic and External Factors to Latin American Devaluation Crises: An Early Warning Systems Approach." That paper developed and simulated a model of financial crises, based on data for six Latin American countries: Argentina, Brazil, Chile, Colombia, Mexico and Venezuela. For this paper, we have extended the database to 26 emerging market countries, and have introduced several (relatively minor) methodological changes as well.

${ }^{2}$ See Hausmann, et. al. (1999) for a comprehensive discussion of the potential benefits that strongly fixed exchange rates could offer for emerging market countries.
} 
reflect adverse external shocks-declines in terms of trade, higher U.S. interest rates, or declines in industrial country output growth-as other observers have argued, then fixing the exchange rate, either through currency boards or dollarization, is more likely to be costly, on balance. It would prevent an adjustment of the exchange rate in response to adverse foreign developments, which might be useful in maintaining economic activity and/or in helping the balance of payments to adjust.

One approach taken to distinguish between the role of domestic and external factors in affecting economic performance has been to estimate a vector-autoregression (VAR) model based on time series of domestic and foreign data. ${ }^{3}$ While useful and important in helping to analyze these issues, the VAR approach is subject to several limitations. First, there often is some ambiguity over what constitutes a "domestic" or an "external" variable. Thus, in some studies, the exchange rate is considered external, while in others it is identified as domestic. Second, the number of variables that can be analyzed simultaneously within a VAR model usually is somewhat limited by the availability of sufficient data. Third, and most importantly, output contractions and financial difficulties in emerging market countries usually have been concentrated in severe crises where key domestic variables experienced sharp dislocations nearly simultaneously, even though the root causes of the crises may have been building up slowly over time. Given that VARs presuppose linear relationships between variables, whereas in practice financial crises tend to have a highly non-linear dependence on their contributing factors, it may be difficult for VAR analyses to appropriately attribute crises to prior accumulations of policy or economic imbalances.

Therefore, as a complement to VAR analysis, in this paper we describe a modified "early warning system" (EWS) approach to identifying the roles of domestic and external factors in emerging

${ }^{3}$ For a recent study along these lines, see Ahmed (1999). Other research in this vein includes Rogers and Wang (1995), Joyce and Kamas (1997), and Hoffmaister and Roldos (1997). 
market crises. In recent years, motivated by the desire to be able to predict financial crises such as those that occurred in Mexico, East Asia, Russia, and Brazil, a substantial literature has emerged focusing on the development of statistical forecasting models for financial crises. ${ }^{4}$ These models typically use both domestic factors (such as money growth) and external factors (such as the terms of trade), as predictive variables. In principle, to the extent that an EWS reliably tracks the past history of financial crises in a country or region, the relative contribution to these crises of the external and domestic variables included in the EWS can be calculated as well.

The basic approach we take in this paper is as follows. First, we identify years during which devaluation crises have occurred in 26 emerging market countries; these countries are identified in Table 1. Second, applying several variants of a probit model to pooled annual data for 1981-1999 for these countries, we estimate the probability of a crisis as a function of a broad set of domestic variables (GDP growth, fiscal deficits, bank loans, M2/reserves, and external debt), variables reflecting external-balance positions (real exchange rates, export growth, foreign direct investment, and current accounts), and more obviously exogenous "external shock" variables (terms of trade, U.S. real short-term interest rates, and industrial country GDP growth). Third, we use the different models we estimated to simulate the probability of crisis over the 1981-1999 period for the countries. Finally, we decompose these probabilities into the parts attributable to domestic factors, external-balance factors, and exogenous external shocks.

In the course of this research, we assess the robustness of our results in several ways. First, in addition to estimating the probit model over data for all of the countries in our sample, we also estimate it over different regional subsets of the data: Latin America, East Asia, and the remaining countries. Second, we estimate the model not only using the crisis-dates identified by our own methodology, but also

\footnotetext{
${ }^{4}$ See Kaminky, Lizondo, and Reinhart (1998), Frankel and Rose (1996), Sachs, Tornell, and Velasco (1996), Berg and Patillo (1999a), International Monetary Fund (1998), Berg, Borensztein, MilesiFerretti and Patillo (1999), Herrera and Garcia (1999), and Glick and Moreno (1999), among others.
} 
using the dates identified by two other approaches employed in the literature.

Section II below describes the methodology employed in the paper in greater detail. Section III summarizes the results, and Section IV concludes.

\section{Description of Methodology}

\section{1 Crisis-dating systems}

The first step in estimating an EWS is to identify periods of financial crisis. For the most part, the literature on predicting financial crises has taken "crisis" to be synonymous with "speculative attack" or extreme pressure on the exchange rate. In consequence, crisis-dating schemes generally have been based on identifying sufficiently sharp changes either in the exchange rate alone (Frankel and Rose, 1996), weighted averages of exchange rates and reserves (Kaminsky, Lizondo, and Reinhart, 1998), or weighted averages of exchange rates, reserves, and interest rates (Eichengreen, Rose, and Wyplosz, 1996).

We broadly follow much of the early warning system literature in constructing measures of exchange rate pressure and identifying periods of greater than normal pressure. The exchange rate pressure variable is constructed as the weighted average of two-month percentage changes in the real bilateral exchange rate against the dollar and in international reserves, with the weights being proportional to the inverse of the standard deviation of these series. Declines in these weighted averages in excess of 1.75 standard deviations indicate a crisis month. ${ }^{5}$

${ }^{5}$ The more standard calculation of exchange rate pressure variables is based on one-month percent changes in exchange rates and reserves. We were concerned that this might rule out cases where reserves or exchange rates fall significantly over longer periods, but not in any one month. Therefore, we experimented with different "window lengths"-e.g., two-month changes, three-month changes, etc.-as well as different crisis thresholds for the exchange rate pressure variable-e.g., one standard deviation, two standard deviations, etc.-in identifying crisis dates. While the estimated probit models were generally robust to changes in these parameters, we found that the fit of the model, as well as the conformance of estimated coefficients with their expected signs, was greatest for "window lengths" and crisis thresholds in the neighborhood of two months and 1.75 standard deviations, 
Since the probit model is estimated using annual data, any year in which a crisis month occurs is considered to be a crisis year. Should additional crisis months be identified in the subsequent year, this is not considered a new crisis unless (1) the exchange rate pressure variable recovers to its prior level before falling significantly again, (2) there is a lapse of more than four months in which no monthly crisis is signaled, or (3) a monthly crisis is signaled after June in the second year.

Figure 1 shows the evolution of crisis dates, based on this approach, over time and for the regional breakdowns. The graph of total crises shows little evidence of any pattern to the occurrence of crises, although there are occasional years when the number of crises spiked. Looking at the regional breakdowns, the number of crises per year clearly slowed in Latin America in the 1990s, while the effect of the 1997 Asian Crisis is clearly visible in the data for that region. Crises in other countries appear to be relatively evenly distributed throughout the sample period.

Table 2(a through c) compares the crisis years identified by this approach-denoted KSS, for Kamin, Schindler, and Samuel-with those identified by two other approaches, as calculated by Edison (2000): (1) Kaminsky, Lizondo, and Reinhart (1998), or KLR; and (2) Frankel and Rose (1996), or FR. A crisis year is denoted by a 1 , and a non-crisis year by a 0 . KLR utilize the exchange rate pressurevariable approach that formed the basis of our own analysis, but focus on nominal rather than real exchange rate changes (with appropriate modifications of the crisis-criterion during periods of high inflation), calculate one-month rather than two-month changes in reserves and exchange rates, and use a threshold of 3 deviations away from the mean, rather than 1.75. FR's approach depends exclusively on annual changes in the nominal exchange rate: year-over-year changes in excess of 25 percent, and exceeding the previous year's change by at least 10 percent, indicate a crisis.

Table 3 summarizes the percentage of agreement between the three crisis dating systems for

respectively. 
each country and for the whole sample. The percentage of agreement between each pair of dating systems is defined as the percentage of times when the first dating system identifies a particular year as a crisis year for a country and the other dating system agrees. ${ }^{6}$ Looking, for example, at the comparison between KSS and KLR, we see that for all countries, KSS and KLR agreed on 61 percent of identified crises years. As expected, KSS is closer to KLR, since they are both based on weighted averages of changes in reserves and exchange rates, than to FR, with which it agreed only 51 percent of the time. These results are mirrored in the correlation coefficients shown at the bottom of the table.

Tables 2 and 3 make clear that different-but plausible-crisis identification schemes frequently lead to differences in the crisis dates being identified. Our approach may, in principle, have some advantages compared with the KLR or FR systems. First, on a conceptual level, it is the depreciation of the real exchange rate rather than the nominal exchange rate that is most likely to be reflective of a financial crisis; an inflation-driven depreciation of the nominal exchange rate may not necessarily indicate a speculative attack, and dividing the sample into high- and low-inflation periods may not be adequate to control for this possibility. Second, on a practical level, using the real exchange rate rather than the nominal rate removes the need for the additional-and especially ad hoc-steps of dividing the sample into high- and low-inflation periods (as in KLR), or of requiring the rate of nominal exchange rate depreciation to exceed that in the prior year by a given margin (as in FR).

Even so, we would not want to overstate the advantages of one crisis-dating system over the others. Moreover, all three approaches to crisis dating raise important concerns. First, since the criteria

${ }^{6}$ The percentage of agreement is calculated by first summing the number of crises identified for each country under one dating system and the number of crises identified for that same country under the other system. Then, the number of times the two systems agree is totaled. Finally, we divide two times the latter sum by the former sum and multiply the resulting quantity by 100 to find the percentage of times that the two systems identified crises at the same time. This methodology is repeated using the entire sample of countries in order to find the agreement for the entire sample. 
for identifying crises are somewhat ad hoc-both in terms of the variables chosen to represent exchange rate pressure and, perhaps more importantly, in the designation of how large a change in them constitutes a crisis-it is difficult to have full confidence that any particular dating system has correctly identified the crises in a sample. ${ }^{7}$

Second, speculative attacks or devaluation episodes do not always coincide with financial or balance-of-payments crises, as evidenced by the United Kingdom's withdrawal from the ERM. Insofar as the raison d'etre of early warning systems-for many policymakers, if not for foreign exchange market participants-is to predict balance-of-payments and/or financial crises, not merely devaluations per se, it would be useful to know how well devaluation episodes are correlated with financial crisis episodes. This consideration is not addressed in this paper, but remains a high priority for future research. ${ }^{8}$

\section{II.2 Explanatory variables}

The EWS literature focuses, broadly speaking, on two types of variables that may help forecast future financial crises: (1) variables reflecting the fundamental determinants of a country's financial position (e.g., current account deficits, real exchange rate misalignment, fiscal deficits, debt-service burdens, repayment capacity), and (2) variables reflecting market expectations of a future crisis or the initial effects of an emerging crisis (e.g., real interest rates, external bond spreads, stock market indexes). The purpose of our analysis is to exploit an EWS model in order to assess the relative weight of different groups of fundamental forces-domestic versus external-in the causes of emerging market financial crises. Therefore, we estimate an EWS whose explanatory variables are comprised solely of

${ }^{7}$ Edison (2000) confirms that relatively innocuous differences in crisis-dating systems can lead to substantial differences in crisis dates.

${ }^{8}$ Kamin and Babson (1999) take a stab at this issue by defining a crisis index based on abnormal declines in imports. They find that modeling results based on this index to be comparable to, and not much better than, results based on more standard exchange rate pressure-based indexes. 
fundamental determinants.

The explanatory variables we selected, based on what prior analyses in the literature had suggested might be important, were the following. (A more detailed description of their calculation is provided in Appendix Table 1. Data sources are shown in Appendix Table 2) Frequently, the literature pointed to a particular variable as being important, e.g., industrial country growth, but not its particular specification: growth rates, deviations of growth from long-term averages, or year-to-year differences in growth rates. The specifications of the explanatory variables used in our model, and described below, are the outcome of a certain amount of trial and error, combined with our prior beliefs as to what a sensible specification might be.

1. Deviation in real GDP growth from its average in prior three years. Increases in GDP growth are expected to lower the probability of crisis, since they reduce pressures to devalue.

2. Ratio of public sector fiscal deficit to GDP. Higher deficits are expected to raise the probability of a crisis, since they increase vulnerability to shocks and lower investor confidence.

3. Three-year domestic bank loan growth. In principle, high loan growth rates are expected to be associated with possible demand pressures, increases in non-performing loans, and hence higher probabilities of financial crisis. However, insofar as bank credit often slows as growth slows and banks foresee problems down the line, higher bank loan growth may be associated with lower crisis probabilities. ${ }^{9}$

4. Three-year growth in ratio of M2 to international reserves. Rising ratios of M2 to reserves are expected to raise crisis probabilities, both because they may reflect excessive domestic credit creation, and because they are associated with a low coverage of central bank liabilities by hard currency. ${ }^{10}$

5. Deviation of external debt-to-exports ratio from long-term average. Higher indebtedness is

${ }^{9}$ Glick and Moreno (1999) point out that if a slowing economy and slowing money demand presage a devaluation, than domestic loan growth might be negatively correlated with devaluation probabilities. In fact, they estimate the contribution of loan growth to the probability of a crisis to be both negative and statistically significant.

${ }^{10}$ This variable has been shown in be quite useful in EWS models. Additionally, Galindo and Maloney (2001) discuss the theoretical underpinnings of this variable and provide empirical support for its role. 
expected to raise vulnerability to a reversal in capital flows and hence to raise the probability of a crisis.

6. Deviation of ratio of international reserves to short-term external debt from long-term average. Higher ratios are assumed to lower vulnerability to liquidity problems and hence lower the probability of a financial crisis.

7. Deviation in real effective exchange rates. High (i.e., appreciated) levels of the real effective multilateral exchange rate, relative to its average for 1980-1997, are believed to be associated with unsustainable external positions and hence are expected to raise the probability of a crisis.

8. Deviation in export growth from its average in prior three years. Increases are expected to indicate a diminished need to devalue and hence to lower the probability of a crisis.

9. Current account balance to GDP ratio. Increases in the surplus are expected to indicate a diminished need to devalue and hence to lower the probability of a crisis.

10. Ratio of foreign direct investment (FDI) to GDP. For a given current account balance (above), a higher amount of FDI implies a lesser share of the current account being financed by more volatile portfolio inflows, and should lower the probability of crisis. Also, higher FDI ratios may be indicative of more attractive economic policies and prospects.

11. Change in percentage growth in terms of trade from prior year. Increases in the terms of trade (export prices over import prices) should strengthen a country's balance-of-payments position and hence lower the probability of crisis.

12. Real U.S. 3-month Treasury bill interest rates. Higher U.S. real interest rates are expected to lead to lower capital inflows, a rise in external debt repayment costs, and hence a higher probability of crisis.

13. Changes in industrial country GDP growth from prior year. Higher foreign growth should strengthen exports and hence lower the probability of a crisis.

Variables 1 through 6 are considered to be domestic variables, in that they are partially or fully

reflective of the country's own policies or other economic conditions. ${ }^{11}$ Variables 11 through 13 are considered to be external-shock variables, since they are almost completely exogenous with respect to the

${ }^{11}$ As several readers have pointed out, it would also be desirable to have a measure of banking sector strength in the model, but we do not know of any variable that is available on a consistent basis across two decades and 26 countries. 
countries themselves. ${ }^{12}$

Finally, variables 7 through 10-the real exchange rate, export growth, the current account-toGDP ratio, and FDI-occupy a more ambiguous or intermediate category. On the one hand, these variables certainly are affected by domestic economic policies and conditions; on the other hand, they also are affected by international capital flows, commodity prices, movements in the foreign exchange value of the U.S. dollar, and other global conditions. In order to abstract from (largely unanswerable) questions of whether these variables are more domestic or external, we place them in a separate category denoted "external-balance variables". Another reason to focus on these variables is that they may be most directly affected by the extent of exchange rate flexibility in the economy.

Based on our identification of crisis years and our selection of explanatory variables, we then estimated a probit model to determine the contribution of the explanatory variables to the probability of a crisis for the emerging market economies in the sample. In this model, the domestic and external-balance variables are entered with a one-year lag; for example, the current account balance in 1981 is used to explain the occurrence of a crisis in 1982. This specification was chosen to correct for likely feedbacks from crises to domestic and external-balance variables. Conversely, external-shock variables enter contemporaneously in the model, reflecting our judgement that they are, for the most part, exogenous with respect to crises or other developments within the country.

Before moving on, we should underscore that there are unavoidable difficulties in categorizing shocks as domestic or external. It was in part for this reason that we placed the factors most likely to reflect both domestic and external influences-the real exchange rate, exports, FDI, and the current account-in the intermediate category of "external-balance" variables. At the same time, however, even

\footnotetext{
${ }^{12}$ For a large economy, the terms of trade might be endogenous with respect to that country's exchange rate, but that is less likely to be true in most emerging market countries.
} 
our domestic variables-GDP growth, fiscal performance, bank lending, the money supply, and measures of accumulated debt-are subject to some foreign influence, given the vulnerability of small emerging market economies to the international economy. We believe that by controlling for the contemporaneous effects of the most important external factors likely to influence emerging market countries-the terms of trade, U.S. interest rates, and industrial country growth-we have allowed the estimated coefficients on the domestic variables to primarily reflect the impact of genuinely domestic factors on the probability of devaluation crises. Nevertheless, we acknowledge the possibility that the estimated impact of the domestic variables may also reflect the effect of external variables that are not controlled for, including lags of our external shock variables or other external factors not included in the model.

\section{Analysis of Results}

\section{III.1 Estimation results}

Bivariate correlations Before moving to a multivariate framework, it is useful to gain a sense of the basic interplay between the explanatory variables and the incidence of crises in our sample. Table 4 compares the mean and median values of the explanatory variables in the year preceding crises and in the years preceding non-crises.

Table 5 presents results of bivariate probit model estimates, in which the explanatory variable-1 if there is a crisis, 0 if there is not-are regressed on lagged (or in the case of the external shock variables, contemporaneous) values of the explanatory variables. The results indicate that for the most part, movements in the explanatory variables are correlated with the incidence of financial crises in the expected manner; however, the tightness of this correlation, as evidenced by the Pseudo $\mathrm{R}^{2}$, is extremely low.

Multivariate analysis We now turn to the probit estimation of the full model, the results of which are shown in Tables 6a. The model is estimated over available data for a maximum date range of 1981-1999, 
although for some countries, data constraints lead to a shorter estimation sample. Table 6a presents the results from estimating "broad" models containing all of the explanatory variables described in Section II.2, using as dependent variables the 0-1 observations defined by the KSS crisis-dating system described in Section II.1. In addition to estimating the model over all 26 of the countries in the sample, as shown in column 1, separate estimates of the model for different subsets of emerging market countries are also shown in columns 2-4.

For each explanatory variable, we show two calculations. The top calculation is $\mathrm{dProb} / \mathrm{dx}$ : the estimated impact on the probability of devaluation stemming from a one unit increase in that variable. For example, in the regression shown in Table $6 \mathrm{a}$, column 1, the $\mathrm{dProb} / \mathrm{dx}$ for the current account/GDP ratio is -0.80. This means that a one unit increase in the current account surplus-say, from 2 percent of GDP to 3 percent of GDP-leads to a 0.8 percentage point decline in the probability of devaluation. The bottom calculation, within parentheses, for each explanatory variable is a " $\mathrm{z}$ " statistic, which has an analogous interpretation to a t-statistic.

Focusing on column 1, the application of the model to all of the countries in the sample, we first note that the Pseudo- $\mathrm{R}^{2}$ is quite low, at 15 percent, but that this is not uncommon for probit models of financial crises. ${ }^{13}$ Additionally, all of the explanatory variables are of the expected sign except reserves/short-term debt, and this is far from significant. Of the other coefficients, four are statistically distinguishable from zero at the 5 percent level of significance and three at roughly the 20 percent level.

However, the model appears not to be uniformly applicable to different subsets of the emerging market countries. The pattern of coefficients in the Latin America regression appears broadly to mirror that of the entire sample. Conversely, in the estimation for the East Asian countries, there are several

\footnotetext{
${ }^{13}$ See Frankel and Rose (1996), Kruger, Osakwe, and Page (1998), Berg and Patillo (1999a), Chinn, Dooley, and Shreshtha (1999), Rodrik and Velasco (1999), and Glick and Moreno (1999), among others.
} 
important sign reversals. In particular, the real exchange rate and current account balance come in with the wrong sign, albeit insignificantly; this is consistent with the generally held view that real exchange rate overvaluation was not at the core of the East Asian financial crises. ${ }^{14}$ Finally, for the remaining countries in the sample, the estimation also yields several sign reversals relative to the "all countries" regression, the most important associated with the real GDP growth and M2/reserves variables.

It is possible that the inclusion of a large number of explanatory variables, many of which are not statistically significant, may introduce a certain amount of noise into the probit estimates. Therefore, for each equation, we sequentially reduced-i.e., "boiled down"-the larger or "broad" initial regressions by deleting the least significant explanatory variables until only significant variables (or marginally significant variables) remained. The resultant "boiled down" regressions are shown in Table 6b.

In the case of the all-countries regression, column 1, the remaining variables all are ones singled out as being important in the literature on financial crises, and also have the expected signs. Columns 2-4 show the results of regressions that have been estimated separately for the data in each region, and that also have been "boiled down" separately so as to allow those variables most important in each region to show through. Consistent with the results for the "broad" regressions shown in Table 6a, there are important differences in the resultant boiled-down equations. No explanatory variables show up in the equations for all three regions.

A final consideration bears on the robustness of the model to differences in crisis-dating schemes. Table 6c compares the estimates of the "broad" model as applied to crises identified by the KSS methodology (column 1) with estimates of this model as applied to the crisis dates deriving from the KLR methodology (column 2) and the FR methodology (column 3). The results using the KSS crisis dates are

${ }^{14}$ Chinn (2001) finds some evidence of real exchange rate overvaluation in some Asian countries prior to the 1997 crisis, but not to a particularly large degree, especially by comparison with the depreciations that followed. 
shown again to facilitate comparison with the results based on the KLR and FR crisis dates, since those latter dates are available for 8 fewer countries than were used in the broad, all-countries regression shown in column 1 of Table 6a. As indicated in column 1 of Table $6 \mathrm{c}$, re-estimating the broad regression over the smaller country data set leaves the pattern of coefficient magnitudes generally unchanged, although significance levels, as indicated by the z-statistics, have declined somewhat. The three crisisdating schemes yield models that are broadly similar in terms of their Pseudo $\mathrm{R}^{2}$ and the pattern of coefficient signs, but there are certainly important differences in the signs, magnitudes, and significance of some of the coefficients as well.

\section{III.2 Simulation results}

Broad, all-countries model Based on the broad all-countries probit model shown in Table 6a, we simulated the probability of a devaluation crisis for every country and for every year of the 1981-99 period for which data were available. ${ }^{15}$ These simulated probabilities are represented by the solid lines in Figures 2a-z, and are denoted "All factors" to indicate that they reflect the estimated contributions of all the explanatory variables in the models. The vertical lines in the charts denote years when financial crises are identified to have actually occurred, based on the KSS crisis-dating system.

As indicated in the charts, for most countries, the estimated probability of devaluation tends to rise during crisis years and decline in non-crisis years, providing some reassurance that the model is reliably correlating devaluation crises with its determinants. Of course, these are in-sample simulations, and so one would expect the model to track history passably well.

Returning to the central motivation for this paper, a key question in the issue of the appropriate

\footnotetext{
${ }^{15}$ This paper does not report out-of-sample forecasting results for two reasons. First, it is not directly relevant to the primary goal of the paper: to decompose estimates of historical crisis probabilities. Second, given the paucity of available observations, dividing the sample to allow for out-of-sample forecasts would unduly limit the data available for estimation.
} 
exchange rate regime for emerging market countries is the extent to which devaluation crises have reflected domestic factors, on the one hand, or external factors, on the other. In order to address this issue, we first re-simulated the probabilities of financial crisis, leaving the domestic and external-balance explanatory variables at their actual values, but replacing each of the external-shock variables-changes in terms of trade growth, real interest rates, and changes in industrial country GDP growth-with their average value over the 1981-99 period. ${ }^{16}$ The results of this simulation are shown as the short-dashed lines of Figures 2a-z, denoted "Domestic and external balance factors". They can be interpreted as the contribution of domestic and external-balance factors alone to the probability of crisis, insofar as externalshock variables would not be expected to contribute to crises provided they remain at their average levels (calculated over two decades).

For the most part, the short-dashed lines in the charts are not far below the solid lines during crisis years. That is, the devaluation probabilities estimated by the probit model are not much lower when only the contributions of domestic and external-balance variables are considered than when external shocks are incorporated as well.

These results represent prima facie evidence that external shocks have not been very important sources of financial and macroeconomic volatility in emerging market countries compared with domestic and external-balance factors. However, as noted above, the external-balance factors included in the model-the real exchange rate, export growth, foreign direct investment, and the current account-may themselves be highly affected by international conditions. Moreover, if certain external-balance variables-particularly large current account deficits and/or overvalued exchange rates-have been contributing to financial crises, that represents a strong argument for flexible exchange rates, even if

\footnotetext{
${ }^{16}$ Glick and Moreno (1999) and Berg and Patillo (1999b) perform conceptually similar experiments, using probits model of crises to examine the contribution of different explanatory variables to the probability of crisis in several Asian and Latin American countries during the mid-1990s.
} 
external shocks per se are not very importance.

Therefore, in order to explore this further, we performed another simulation, denoted "Domestic factors only", in which both the external-shock variables and the external-balance variables were set to their mean levels, so that estimated movements in crisis probabilities reflected movements in domestic variables alone. ${ }^{17}$ As may be seen in Figures $2 \mathrm{a}-\mathrm{z}$, in some countries, domestic factors alone, denoted by the long- and short-dashed line, still account for most of the estimated crisis probabilities, but the picture is somewhat murkier for other countries.

In order to make more sense of these results, they are summarized in Table 7a. Column 1 indicates, for each country and based on the broad model estimated for all 26 countries in the sample, the average simulated probability of crisis during all of the non-crisis years identified for that country. Column 2 presents the analogous calculation of the average simulated probability of crisis during the crisis years. As one would hope, the model's estimated probability of crisis generally is higher for crisis years than for non-crisis years; if this were not the case, the model would not provide very credible evidence on the relative role of domestic and external factors in contributing to crises.

Column 3 shows the average contributions of domestic factors alone to the estimated probability of crisis during crisis years, once the effect of external-balance and external-shock variables are removed. Column 4 shows the average contributions of external-balance factors to crisis probabilities during those years when crises were identified, while column 5 shows the average contributions of the external-shock variables. These results confirm what already is apparent in Figures 2a-z: external-shock

${ }^{17}$ Setting the external-balance variables to their average levels may be a less compelling means of nullifying their estimated contribution to crises than is the case for the external shock variables, but is a reasonable first cut at this problem. This is clearly an appropriate strategy for the real exchange rate variable, which is defined as a deviation from its average, and for export growth, which is defined as deviations from prior growth. For the current account/GDP and FDI/GDP ratios, the justification for assuming that at their means, they do not contribute to crises, is that their averages over two-decade periods presumably are reflective of their longer-term sustainable levels. 
variables, by themselves, are estimated to have contributed little to the simulated probability of devaluation crises among emerging market countries. ${ }^{18}$ Moreover, the contribution of external-balance variables, by themselves, also seems small compared with the contribution of domestic factors. On the face of it, these results all point to the primacy of domestic factors in contributing to crises in emerging market countries.

However, these results, by themselves, may be misleading. The estimated contribution of domestic factors shown in column 3 is calculated residually, once the contributions of the external-shock (column 4) and external-balance factors (column 5) are removed from the total estimated probability of crisis (column 2). This residual undoubtedly incorporates the important effects of domestic factors on the probability of financial crisis. However, it may also reflect, to some extent, the imprecision of the model's estimates: the inability to predict crises with certainty, when they arise, must have at its counterpart a certain minimum estimate of the probability of crisis during all years, crisis or non-crisis alike. Therefore, it is likely that this minimum crisis probability is incorporated into the estimated domestic contribution to the probability of crisis. This conjecture is consistent with the fact that, on average over the countries in the sample (see the bottom line), the estimated domestic contribution during crisis years (column 3) is similar in value to the average probability of crisis during non-crisis years (column 1).

To investigate this issue further, we calculate, for each of the three factors-domestic, external balance, and external shock-the difference between their contributions to crisis probabilities during crisisyears and during non-crisis years. The purpose of this is to calculate the contribution of each factor to the increase in the probability of crisis estimated for crisis years relative to non-crisis years. As may be seen in the bottom line of the table, in columns 6 through 8 , these calculations yield a very different story than those for columns 3 through 5. On balance over the countries in the sample, domestic factors account for

\footnotetext{
${ }^{18}$ The negative numbers in Column 4 and 5 for certain countries indicate that in those cases, external and external-balance shocks are believed to have reduced, not increased, the probabilities of a crisis.
} 
little of the estimated increase in crisis probabilities associated with crisis years, while external-balance and external shock factors account for much more of the increase.

How do we interpret the conflicting results in columns 6-8 compared with 3-5? Our interpretation is that the domestic contribution to the probability of crisis shown in column 3, while perhaps incorporating some of the imprecision of the model noted above, also reflects genuine effects of domestic policy and economic imbalances on countries' vulnerability to financial crisis. However, these domestic effects may be somewhat less prone to swings over time than the external-balance and external-shock factors. It is these latter factors, when they move adversely, which compound the effects of the domestic imbalances, raise probabilities of crisis to more dangerous levels, and hence push countries over the edge and into crisis. To the extent that this is the case, it suggests that neither domestic nor external factors can be singled out as primary factors in emerging market crises.

A final point worth noting is that the relative proportions of the contribution to crisis probabilities, or to changes in crisis probabilities, varies from country to country and region to region. In Latin America, for example, external balance factors appear to account for a greater contribution to changes in crisis probabilities than do external shocks. The reverse appears to be true in Asia. Hence, even if one factor is predominant on balance across countries, individual economies may be subject to very different sources of vulnerability.

$\underline{\text { Robustness tests }}$ As noted in Section III.1 above, the pattern of coefficient signs and magnitudes exhibited important changes when the probit model was estimated over data for different emerging market regions, compared with the all-countries regression. Additionally, estimation based on two other crisis-dating schemes, the KLR and FR approaches, led to different coefficients compared to the model applied to the KSS crisis-dating scheme. In principle, decomposition of the model results to identify the sources of financial crises could yield different outcomes, if based on different estimated models. To 
explore the robustness of our results to different country datasets and different crisis-dating schemes, we repeated the decomposition exercise shown in Table 7a, based on different estimated models.

Table $7 \mathrm{~b}$ presents analogous calculations to Table 7a. However, the simulation results for each region are based on the broad regression results estimated over that region's data alone; hence, the decomposition of crisis probabilities for Latin America is based on the broad regression estimated using Latin American data (Table 6a, column 2), the Asian decomposition is based on the Asian broad regression (Table 6a, column 3), and the "other" decomposition on the "other" regression (Table 6a, column 4).

Table $7 \mathrm{c}$ and $7 \mathrm{~d}$ are analogous to Table $7 \mathrm{a}$ and $7 \mathrm{~b}$, but based on the boiled-down regressions (Table $6 \mathrm{~b}$ ) rather than the broad regressions (Table 6a). Table $7 \mathrm{e}$ and $7 \mathrm{f}$ are based on the broad, allcountries regressions that used the KLR and FR crisis dates as their dependent variable, as shown in Table 6c.

The message from all of these tables is similar. The contribution of external-shock and externalbalance variables to the average probability of crisis during crisis years is generally low compared to the estimated contribution of domestic factors. However, their contributions to increases in estimated probabilities from non-crisis to crisis years generally is higher than that of domestic factors.

\section{Conclusion}

In this paper, we developed a modified "early warning system" (EWS) approach to identifying the roles of domestic and external factors in emerging market crises. Several probit models of balance-ofpayments crises were estimated for 26 emerging market countries, using both external and domestic variables. These models were then used to simulate the probability of crisis over the 1981-1999 period in each country. Finally, we re-simulated the models in order to identify the separate contributions to the probability of crises of domestic, external-balance, and external-shock variables. 
An important finding is that our probit models yielded quite different results, depending upon the region and the crisis-dating system used in the estimation. This suggests that future research into the causes of emerging market crises, and into means of predicting future crises, should keep regional differences in mind.

Notwithstanding differences in regional results and differences using alternative crisis-dating schemes, however, the key findings of our research were quite robust. Relative to the effects of domestic factors, both external shocks (to the terms of trade, U.S. interest rates, or industrial country growth) and external-balance variables (export growth, the real exchange rate, FDI, and the current account balance) made relatively small contributions to the probability of financial crisis in each sample country, as estimated on average over the years in the sample. However, external-shock and externalbalance variables made a greater contribution than domestic variables to the increases in crisis probabilities that were estimated to occur during actual crisis years. This was true on balance for all the countries in the sample, although the relative importance of domestic, external-balance, and externalshock factors varied from country to country, and also were affected to some degree by choice of model and choice of crisis-dating scheme.

We interpret these findings as suggesting that, over time in most emerging market countries, domestic factors have maintained a relatively steady contribution to vulnerability to financial crisis, reflecting on-going fiscal deficits, monetary creation, over-borrowing, and other such factors. Conversely, external-shock and external-balance variables have exerted greater swings over time, reducing crisis probabilities when they moved in beneficial ways and raising these probabilities during adverse movements. Adverse swings in these external factors, against the background of already-high levels of vulnerability attributable to domestic factors, likely pushed emerging market countries into crisis on many occasions. 
To the extent that this interpretation holds true, it suggests that no factors-domestic, external balance, or external shock-can be singled out either as unimportant in causing financial crises or as predominant in that regard. As regards the debate over appropriate exchange rate regimes for emerging market countries, the implication is that there may indeed be a cost to eliminating exchange rate flexibility. Such flexibility may help to cushion the impact of external shocks, and may also be useful in preventing the emergence of severe cases of exchange rate misalignment and/or severe cases of external imbalance.

Even so, we would stress that for some countries in our sample, the contribution of domestic factors to crisis probabilities, and even to increases in crisis probabilities during crisis years, appears to have exceeded that of external factors-see the Philippines, for example. For such countries, the benefits of exchange rate fixity might well exceed the cost of giving up exchange rate flexibility, insofar as external factors have not been particularly important for their crises. Hence, our results do not lend themselves to a one-size-fits-all approach toward exchange rate regimes. The choice of exchange rate regime accordingly remains a difficult decision with uncertain ramifications.

While our findings are well within the mainstream of conventional thinking, we would nonetheless underscore several limitations of our study. First, this econometric research is preliminary, and more broadly, the development of empirical models to predict financial crises is still at an early stage. Therefore, considerable more work will be required to confirm the reliability of our findings.

Second, as noted earlier, the domestic variables in the model-GDP growth, fiscal performance, monetary growth, and accumulated debt-may be subject to influence by external developments, notwithstanding the fact that the model controls for external shocks. Additionally, the residuallycalculated contributions of domestic variables to the average probability of crisis may to some extent incorporate the effects of the model's inability to track crises precisely, which leads to non-zero estimates of crisis probabilities, even during non-crisis years. Hence, the contribution of domestic factors to crises 
may be somewhat lower, and the contribution of external factors somewhat higher, than estimated in our paper.

Third, adverse external shocks are not the only developments that, ideally, might call for a flexible response by exchange rates in order to moderate negative impacts. A decline in productivity, or an exogenous increase in demand for imports, should also lead to a lower exchange rate. Hence, even if domestic factors are shown to have been the most important cause of crises for some countries, these factors could reflect real as well as monetary shocks, and hence may not constitute a strong rationale for giving up exchange rate flexibility.

Finally, whatever the sources of financial crises in the past, it is not clear that they will remain the same going forward. Our sense is that, compared with the 1980s, emerging market countries in recent years have exhibited more macroeconomic discipline, and this has been associated with lower fiscal deficits and lower inflation. Hence, we would not be surprised if, in the future, the role of domestic policy imbalances in the propagation of financial crises diminished relative to that of external factors. All else equal, this, too, might weaken the case for strongly fixed exchange rates relative to more flexible regimes. 


\section{REFERENCES}

Ahmed, Shaghil (1999), "Sources of Economic Fluctuations in Latin America and Implications for Choice of Exchange Rate Regimes," Board of Governors of the Federal Reserve System, International Finance Discussion Paper Number 656.

Berg, Andrew and Catherine Patillo (1999a), "Are Currency Crises Predictable? A Test, " IMF Staff Papers, Vol. 46, Number 2, pp. 107-38.

(1999b), "What Caused the Asian Crisis: An Early Warning System Approach,”Economic

Notes, Vol. 28, Number 3, pp. 285-334.

Berg, Andrew, Eduardo Borensztein, Gian Maria Milesi-Ferretti, and Catherine Patillo (1999),

"Anticipating Balance of Payments Crises: The Role of Early Warning Systems," IMF Occasional

Paper Number 186.

Chinn, Menzie D. (2001), “Before the Fall: Were East Asian Currencies Overvalued?” Emerging

Markets Review, Volume 1, Number 2.

Chinn, Menzie D., Michael P. Dooley, and Sona Shrestha (1999), "Latin America and East Asia in the Context of an Insurance Model of Currency Crises," Journal of International Money and Finance, Volume 18, Number 4.

Edison, Hali (2000), "Do Indicators of Financial Crises Work? An Evaluation of an Early Warning System," Board of Governors of the Federal Reserve System, International Finance Discussion Paper Number 675.

Eichengreen, Barry, Andrew Rose, and Charles Wyplosz (1995), "Exchange Market Mayhem: The Antecedents and Aftermath of Speculative Attacks," Economic Policy, 21, October, 249-312.

Frankel, Jeffrey and Andrew Rose (1996), "Currency Crashes in Emerging Markets. An Empirical Treatment,” Journal of International Economics, 41, November, 351-366.

Galindo, Arturo J. and William F. Maloney (2001), "Second Moments in Speculative Attack Models: Panel Evidence," Journal of International Economics, forthcoming.

Glick, Reuven and Ramon Moreno (1999), "Money and Credit, Competitiveness, and Currency Crises in Asia and Latin America," Federal Reserve Bank of San Francisco Center for Pacific Basin Working Paper No. PB99-01, March.

Hausmann, Ricardo, Michael Gavin, Carmen Pages-Serra, and Ernesto Stein (1999), "Financial Turmoil and the Choice of Exchange Rate Regime", Inter-American Development Bank, Office of the 
Chief Economist, mimeo.

Herrera, Santiago and Conrado Garcia (1999), “A User's Guide to an Early Warning System of Macroeconomic Vulnerability for LAC Countries," The World Bank, mimeo.

Hoffmaister, Alexander W. and Jorge E. Roldos (1997), “Are Business Cycles Different in Asia and Latin America?’ International Monetary Fund, mimeo.

International Monetary Fund (1998), "Chapter IV. Financial Crises: Characteristics and Indicators of Vulnerability," in World Economic Outlook, Washington D.C., May.

Joyce, Joseph and Linda Kamas (1997), "The Relative Importance of Foreign and Domestic Shocks to Output and Prices in Mexico and Colombia," Weltwirtschaftliches Archiv,...

Kamin, Steven B. and Oliver D. Babson (1999), “The Contributions of Domestic and External Factors to Latin American Devaluation Crises: An Early Warning Systems Approach," Board of Governors of the Federal Reserve System, International Finance Discussion Paper No. 645, September.

Kaminsky, Graciela Saul Lizondo, and Carmen Reinhart (1998), "Leading Indicators of Currency Crises," International Monetary Fund Staff Papers, 45, No. 1, March,1-48.

Kruger, Mark, Patrick N. Osakwe and Jennifer Page (1998), "Fundamentals, Contagion and Currency Crises: An Empirical Analysis,” Bank of Canada Working Paper, July.

Rodrik, Dani and Andres Velasco (1999), “Short-term Capital Flows,” mimeo, April.

Rogers, John H. and Ping Wang (1995), “Output, Inflation and Stabilization in a Small Open Economy: Evidence from Mexico,” Journal of Development Economics 46 (2), 271-293.

Sachs, Jeffry, Aaron Tornell, and Andres Velasco (1996), "Financial Crises in Emerging Markets. The Lessons from 1995," Brookings Papers on Economic Activity, 1:147-215. 
Table 1

Country List

Latin America

Argentina

Brazil

Chile

Colombia

Ecuador

Mexico

Peru

Uruguay

Venezuela
East Asia

China

Indonesia

Malaysia

Korea

Philippines

Taiwan

Thailand
Other

Egypt

Hungary

India

Israel

Morocco

Pakistan

Poland

Saudi Arabia

South Africa

Turkey 
Table $2 \mathrm{a}$

\section{Comparing Currency Crisis Dating Systems}

Latin America

\begin{tabular}{ccccccccccccccccc}
\multicolumn{4}{c}{ Argentina } & \multicolumn{3}{c}{ Brazil } & \multicolumn{1}{c}{ Chile } & \multicolumn{3}{c}{ Colombia } & \multicolumn{3}{c}{ Ecuador } \\
\hline & KSS & KLR & FR & KSS & KLR & FR & KSS & KLR & FR & KSS & KLR & FR & KSS & KLR & FR \\
\hline 1980 & 0 & 0 & 1 & 1 & 0 & 0 & 0 & 0 & 0 & 0 & 0 & 0 & 0 & - & - \\
1981 & 1 & 0 & 1 & 0 & 0 & 1 & 0 & 0 & 0 & 0 & 0 & 0 & 0 & - & - \\
1982 & 1 & 1 & 0 & 1 & 1 & 0 & 1 & 0 & 1 & 0 & 0 & 0 & 1 & - & - \\
1983 & 0 & 0 & 0 & 0 & 0 & 1 & 0 & 0 & 0 & 1 & 0 & 0 & 1 & - & - \\
1984 & 0 & 0 & 1 & 0 & 0 & 0 & 1 & 0 & 0 & 1 & 0 & 0 & 1 & - & - \\
1985 & 0 & 0 & 0 & 0 & 0 & 0 & 1 & 1 & 1 & 1 & 1 & 1 & 1 & - & - \\
1986 & 0 & 0 & 0 & 0 & 0 & 0 & 0 & 0 & 0 & 0 & 0 & 0 & 1 & - & - \\
1987 & 0 & 0 & 1 & 0 & 0 & 1 & 0 & 0 & 0 & 0 & 0 & 0 & 0 & - & - \\
1988 & 0 & 0 & 0 & 0 & 0 & 0 & 0 & 0 & 0 & 0 & 0 & 0 & 1 & - & - \\
1989 & 1 & 1 & 0 & 1 & 0 & 0 & 0 & 0 & 0 & 0 & 0 & 0 & 0 & - & - \\
1990 & 0 & 0 & 0 & 1 & 1 & 0 & 0 & 0 & 0 & 0 & 0 & 0 & 0 & - & - \\
1991 & 1 & 0 & 0 & 1 & 1 & 0 & 0 & 0 & 0 & 0 & 0 & 0 & 0 & - & - \\
1992 & 0 & 0 & 0 & 0 & 0 & 1 & 0 & 0 & 0 & 0 & 0 & 0 & 0 & - & - \\
1993 & 0 & 0 & 0 & 0 & 0 & 0 & 0 & 0 & 0 & 0 & 0 & 0 & 0 & - & - \\
1994 & 0 & 0 & 0 & 0 & 0 & 0 & 0 & 0 & 0 & 0 & 0 & 0 & 0 & - & - \\
1995 & 0 & 0 & 0 & 0 & 0 & 0 & 0 & 0 & 0 & 0 & 0 & 0 & 0 & - & - \\
1996 & 0 & 0 & 0 & 0 & 0 & 0 & 0 & 0 & 0 & 0 & 0 & 0 & 0 & - & - \\
1997 & 0 & 0 & 0 & 0 & 0 & 0 & 0 & 0 & 0 & 1 & 1 & 1 & 0 & - & - \\
1998 & 0 & 0 & 0 & 1 & 0 & 0 & 0 & 0 & 0 & 1 & 1 & 0 & 0 & - & - \\
1999 & 0 & 0 & 0 & 1 & 1 & 0 & 0 & 0 & 0 & 1 & 1 & 0 & 1 & - & - \\
\hline Total & 4 & 2 & 4 & 7 & 4 & 4 & 3 & 1 & 2 & 6 & 4 & 2 & 7 & - & - \\
\hline
\end{tabular}

\begin{tabular}{ccccccccccccc} 
& \multicolumn{3}{c}{ Mexico } & \multicolumn{3}{c}{ Peru } & \multicolumn{3}{c}{ Uruguay } & \multicolumn{3}{c}{ Venezuela } \\
\hline & KSS & KLR & FR & KSS & KLR & FR & KSS & KLR & FR & KSS & KLR & FR \\
\hline 1980 & 0 & 0 & 0 & 0 & 0 & 0 & 0 & 0 & 0 & 0 & 0 & 0 \\
1981 & 0 & 0 & 0 & 0 & 0 & 1 & 0 & 0 & 0 & 0 & 0 & 0 \\
1982 & 1 & 1 & 1 & 0 & 0 & 1 & 1 & 1 & 1 & 0 & 0 & 0 \\
1983 & 0 & 0 & 0 & 0 & 0 & 0 & 0 & 0 & 0 & 0 & 0 & 0 \\
1984 & 0 & 0 & 0 & 0 & 0 & 0 & 1 & 0 & 1 & 1 & 1 & 1 \\
1985 & 1 & 0 & 1 & 0 & 0 & 1 & 1 & 0 & 0 & 0 & 0 & 0 \\
1986 & 0 & 0 & 0 & 0 & 0 & 0 & 0 & 0 & 0 & 1 & 1 & 1 \\
1987 & 0 & 0 & 0 & 1 & 1 & 1 & 0 & 0 & 0 & 0 & 0 & 0 \\
1988 & 0 & 0 & 0 & 1 & 0 & 0 & 0 & 0 & 0 & 0 & 0 & 0 \\
1989 & 0 & 0 & 0 & 0 & 0 & 0 & 1 & 0 & 1 & 1 & 1 & 1 \\
1990 & 0 & 0 & 0 & 0 & 0 & 1 & 0 & 0 & 0 & 0 & 0 & 0 \\
1991 & 0 & 0 & 0 & 0 & 0 & 0 & 0 & 0 & 0 & 0 & 0 & 0 \\
1992 & 0 & 0 & 0 & 0 & 0 & 0 & 0 & 0 & 0 & 0 & 0 & 0 \\
1993 & 0 & 0 & 0 & 0 & 0 & 1 & 0 & 0 & 0 & 0 & 0 & 1 \\
1994 & 1 & 1 & 1 & 0 & 0 & 0 & 0 & 0 & 0 & 1 & 0 & 1 \\
1995 & 1 & 0 & 0 & 0 & 0 & 0 & 0 & 0 & 0 & 0 & 1 & 0 \\
1996 & 0 & 0 & 0 & 0 & 0 & 0 & 0 & 0 & 0 & 1 & 0 & 1 \\
1997 & 0 & 0 & 0 & 0 & 0 & 0 & 0 & 0 & 0 & 0 & 0 & 0 \\
1998 & 0 & 0 & 1 & 0 & 0 & 0 & 0 & 0 & 0 & 0 & 0 & 0 \\
1999 & 0 & 0 & 0 & 0 & 0 & 0 & 0 & 0 & 0 & 0 & 0 & 0 \\
\hline Total & 4 & 2 & 4 & 2 & 1 & 6 & 4 & 1 & 3 & 5 & 4 & 6 \\
\hline
\end{tabular}

Notes: KSS = Kamin-Schindler-Samuel, KLR = Kaminsky-Lizondo-Reinhart, FR = Frankel-Rose

Crisis dummy variables $=1$ if crisis in period $\mathrm{t},=0$ otherwise. A dash (-) denotes countries not included in dataset. 
Table 2b

\section{Comparing Currency Crisis Dating Systems}

East Asia

\begin{tabular}{ccccccccccccccccc} 
& \multicolumn{4}{c}{ China } & \multicolumn{4}{c}{ Indonesia } & \multicolumn{1}{c}{ Korea } & \multicolumn{3}{c}{ Malaysia } & \multicolumn{3}{c}{ Philippines } \\
\hline & KSS & KLR & FR & KSS & KLR & FR & KSS & KLR & FR & KSS & KLR & FR & KSS & KLR & FR \\
\hline 1980 & 1 & - & - & 0 & 0 & 0 & 1 & 1 & 1 & 0 & 0 & 0 & 0 & 0 & 0 \\
1981 & 1 & - & - & 0 & 0 & 0 & 0 & 0 & 0 & 0 & 0 & 0 & 0 & 0 & 0 \\
1982 & 0 & - & - & 0 & 0 & 0 & 1 & 0 & 0 & 1 & 0 & 0 & 0 & 0 & 0 \\
1983 & 0 & - & - & 1 & 1 & 1 & 0 & 0 & 0 & 0 & 0 & 0 & 1 & 1 & 1 \\
1984 & 1 & - & - & 0 & 0 & 0 & 0 & 0 & 0 & 0 & 0 & 0 & 1 & 1 & 0 \\
1985 & 0 & - & - & 0 & 0 & 0 & 0 & 0 & 0 & 1 & 0 & 0 & 0 & 0 & 0 \\
1986 & 1 & - & - & 1 & 1 & 1 & 0 & 0 & 0 & 1 & 0 & 0 & 1 & 1 & 0 \\
1987 & 0 & - & - & 0 & 0 & 0 & 0 & 0 & 0 & 0 & 0 & 0 & 0 & 0 & 0 \\
1988 & 0 & - & - & 0 & 0 & 0 & 0 & 0 & 0 & 0 & 0 & 0 & 0 & 0 & 0 \\
1989 & 1 & - & - & 0 & 0 & 0 & 0 & 0 & 0 & 0 & 0 & 0 & 0 & 0 & 0 \\
1990 & 1 & - & - & 0 & 0 & 0 & 0 & 0 & 0 & 0 & 0 & 0 & 1 & 0 & 0 \\
1991 & 0 & - & - & 0 & 0 & 0 & 0 & 0 & 0 & 0 & 0 & 0 & 0 & 0 & 0 \\
1992 & 1 & - & - & 0 & 0 & 0 & 0 & 0 & 0 & 0 & 0 & 0 & 0 & 0 & 0 \\
1993 & 0 & - & - & 0 & 0 & 0 & 0 & 0 & 0 & 0 & 0 & 0 & 0 & 0 & 0 \\
1994 & 1 & - & - & 0 & 0 & 0 & 0 & 0 & 0 & 0 & 0 & 0 & 0 & 0 & 0 \\
1995 & 0 & - & - & 0 & 0 & 0 & 0 & 0 & 0 & 0 & 0 & 0 & 0 & 0 & 0 \\
1996 & 0 & - & - & 0 & 0 & 0 & 0 & 0 & 0 & 0 & 0 & 0 & 0 & 0 & 0 \\
1997 & 0 & - & - & 1 & 1 & 1 & 1 & 1 & 1 & 1 & 1 & 1 & 1 & 1 & 1 \\
1998 & 0 & - & - & 0 & 0 & 0 & 0 & 0 & 0 & 1 & 0 & 0 & 0 & 0 & 0 \\
1999 & 0 & - & - & 0 & 0 & 0 & 0 & 0 & 0 & 0 & 0 & 0 & 0 & 0 & 0 \\
\hline Total & 8 & - & - & 3 & 3 & 3 & 3 & 2 & 2 & 5 & 1 & 1 & 5 & 4 & 2 \\
\hline
\end{tabular}

\begin{tabular}{ccccccc} 
& \multicolumn{3}{c}{ Taiwan } & \multicolumn{3}{c}{ Thailand } \\
\hline & KSS & KLR & FR & KSS & KLR & FR \\
\hline 1980 & 1 & - & - & 1 & 0 & 0 \\
1981 & 0 & - & - & 1 & 0 & 0 \\
1982 & 0 & - & - & 1 & 0 & 0 \\
1983 & 0 & - & - & 0 & 0 & 0 \\
1984 & 0 & - & - & 0 & 0 & 0 \\
1985 & 0 & - & - & 1 & 0 & 0 \\
1986 & 0 & - & - & 0 & 0 & 0 \\
1987 & 0 & - & - & 0 & 0 & 0 \\
1988 & 0 & - & - & 0 & 0 & 0 \\
1989 & 1 & - & - & 0 & 0 & 0 \\
1990 & 1 & - & - & 0 & 0 & 0 \\
1991 & 0 & - & - & 0 & 0 & 0 \\
1992 & 0 & - & - & 0 & 0 & 0 \\
1993 & 0 & - & - & 0 & 0 & 0 \\
1994 & 0 & - & - & 0 & 0 & 0 \\
1995 & 1 & - & - & 0 & 0 & 0 \\
1996 & 0 & - & - & 0 & 0 & 0 \\
1997 & 1 & - & - & 1 & 1 & 1 \\
1998 & 0 & - & - & 1 & 0 & 0 \\
1999 & 0 & - & - & 0 & 0 & 0 \\
\hline Total & 5 & - & - & 6 & 1 & 1 \\
\hline
\end{tabular}

Notes: KSS = Kamin-Schindler-Samuel, KLR = Kaminsky-Lizondo-Reinhart, FR = Frankel-Rose

Crisis dummy variables $=1$ if crisis in period $t,=0$ otherwise. A dash (-) denotes countries not included in dataset. 
Table 2c

\section{Comparing Currency Crisis Dating Systems}

Other Countries

\begin{tabular}{|c|c|c|c|c|c|c|c|c|c|c|c|c|c|c|c|}
\hline & \multicolumn{3}{|c|}{ Egypt } & \multicolumn{3}{|c|}{ Hungary } & \multicolumn{3}{|c|}{ India } & \multicolumn{3}{|c|}{ Israel } & \multicolumn{3}{|c|}{ Morocco } \\
\hline & KSS & KLR & FR & KSS & KLR & FR & KSS & KLR & FR & KSS & KLR & FR & KSS & KLR & FR \\
\hline 1980 & $\overline{0}$ & - & - & 0 & - & - & 0 & 0 & 0 & 0 & $\overline{0}$ & 0 & 1 & - & - \\
\hline 1981 & 0 & - & - & 0 & - & - & 0 & 0 & 0 & 1 & 0 & 0 & 1 & - & - \\
\hline 1982 & 0 & - & - & 0 & - & - & 0 & 0 & 0 & 0 & 0 & 0 & 0 & - & - \\
\hline 1983 & 0 & - & - & 0 & - & - & 0 & 0 & 0 & 0 & 1 & 1 & 1 & - & - \\
\hline 1984 & 0 & - & - & 0 & - & - & 0 & 0 & 0 & 1 & 1 & 0 & 0 & - & - \\
\hline 1985 & 0 & - & - & 0 & - & - & 0 & 0 & 0 & 1 & 0 & 0 & 0 & - & - \\
\hline 1986 & 0 & - & - & 0 & - & - & 0 & 0 & 0 & 0 & 0 & 0 & 0 & - & - \\
\hline 1987 & 0 & - & - & 0 & - & - & 0 & 0 & 0 & 0 & 0 & 0 & 0 & - & - \\
\hline 1988 & 0 & - & - & 0 & - & - & 0 & 0 & 0 & 0 & 0 & 0 & 0 & - & - \\
\hline 1989 & 1 & - & - & 0 & - & - & 0 & 0 & 0 & 1 & 0 & 0 & 0 & - & - \\
\hline 1990 & 1 & - & - & 0 & - & - & 1 & 0 & 0 & 0 & 0 & 0 & 1 & - & - \\
\hline 1991 & 1 & - & - & 0 & - & - & 1 & 1 & 1 & 0 & 0 & 0 & 0 & - & - \\
\hline 1992 & 0 & - & - & 0 & - & - & 0 & 0 & 0 & 0 & 0 & 0 & 1 & - & - \\
\hline 1993 & 0 & - & - & 1 & - & - & 1 & 1 & 0 & 0 & 0 & 0 & 0 & - & - \\
\hline 1994 & 0 & - & - & 0 & - & - & 0 & 0 & 0 & 0 & 0 & 0 & 0 & - & - \\
\hline 1995 & 0 & - & - & 0 & - & - & 1 & 0 & 0 & 0 & 0 & 0 & 0 & - & - \\
\hline 1996 & 0 & - & - & 0 & - & - & 0 & 0 & 0 & 0 & 0 & 0 & 0 & - & - \\
\hline 1997 & 0 & - & - & 1 & - & - & 0 & 0 & 0 & 0 & 0 & 0 & 0 & - & - \\
\hline 1998 & 0 & - & - & 0 & - & - & 0 & 0 & 0 & 0 & 0 & 0 & 0 & - & - \\
\hline 1999 & 0 & - & - & 0 & - & - & 0 & 0 & 0 & 0 & 0 & 0 & 0 & - & - \\
\hline \multirow[t]{3}{*}{ Total } & 3 & - & - & 2 & - & - & 4 & 2 & 1 & 4 & 2 & 1 & 5 & - & - \\
\hline & \multicolumn{3}{|c|}{ Pakistan } & \multicolumn{3}{|c|}{ Poland } & \multicolumn{3}{|c|}{ Saudi Arabia } & \multicolumn{3}{|c|}{ South Africa } & \multicolumn{3}{|c|}{ Turkey } \\
\hline & KSS & KLR & FR & KSS & KLR & FR & KSS & KLR & FR & KSS & KLR & FR & KSS & KLR & FR \\
\hline 1980 & 0 & $\overline{0}$ & 0 & 0 & - & - & 0 & - & - & 0 & $\overline{0}$ & 0 & 1 & 1 & 1 \\
\hline 1981 & 0 & 0 & 0 & 0 & - & - & 0 & - & - & 0 & 0 & 1 & 1 & 0 & 0 \\
\hline 1982 & 1 & 0 & 1 & 0 & - & - & 0 & - & - & 0 & 0 & 0 & 0 & 0 & 1 \\
\hline 1983 & 0 & 0 & 0 & 0 & - & - & 0 & - & - & 0 & 0 & 0 & 1 & 0 & 0 \\
\hline 1984 & 0 & 0 & 0 & 0 & - & - & 0 & - & - & 1 & 1 & 1 & 1 & 0 & 1 \\
\hline 1985 & 1 & 0 & 0 & 0 & - & - & 1 & - & - & 0 & 1 & 0 & 0 & 0 & 0 \\
\hline 1986 & 0 & 0 & 0 & 0 & - & - & 1 & - & - & 1 & 1 & 0 & 0 & 0 & 0 \\
\hline 1987 & 0 & 0 & 0 & 0 & - & - & 0 & - & - & 0 & 0 & 0 & 0 & 0 & 0 \\
\hline 1988 & 0 & 0 & 0 & 0 & - & - & 0 & - & - & 0 & 0 & 0 & 0 & 0 & 1 \\
\hline 1989 & 1 & 0 & 0 & 1 & - & - & 0 & - & - & 0 & 0 & 0 & 0 & 0 & 0 \\
\hline 1990 & 0 & 0 & 0 & 0 & - & - & 0 & - & - & 0 & 0 & 0 & 0 & 0 & 0 \\
\hline 1991 & 0 & 0 & 0 & 0 & - & - & 0 & - & - & 0 & 0 & 0 & 1 & 0 & 1 \\
\hline 1992 & 0 & 0 & 0 & 0 & - & - & 1 & - & - & 0 & 0 & 0 & 0 & 0 & 0 \\
\hline 1993 & 0 & 0 & 0 & 0 & - & - & 0 & - & - & 0 & 0 & 0 & 0 & 0 & 0 \\
\hline 1994 & 0 & 0 & 0 & 0 & - & - & 0 & - & - & 0 & 0 & 0 & 1 & 1 & 1 \\
\hline 1995 & 1 & 0 & 0 & 0 & - & - & 0 & - & - & 0 & 0 & 0 & 0 & 0 & 0 \\
\hline 1996 & 1 & 0 & 0 & 0 & - & - & 0 & - & - & 1 & 0 & 1 & 0 & 0 & 1 \\
\hline 1997 & 1 & 0 & 0 & 0 & - & - & 0 & - & - & 0 & 0 & 0 & 0 & 0 & 0 \\
\hline 1998 & 1 & 0 & 0 & 0 & - & - & 0 & - & - & 1 & 1 & 1 & 0 & 0 & 0 \\
\hline 1999 & 0 & 0 & 0 & 0 & - & - & 0 & - & - & 0 & 0 & 0 & 0 & 0 & 0 \\
\hline Total & 7 & 0 & 1 & 1 & - & - & 3 & - & - & 4 & 4 & 4 & 6 & 2 & 7 \\
\hline
\end{tabular}

Notes: KSS = Kamin-Schindler-Samuel, KLR $=$ Kaminsky-Lizondo-Reinhart, FR = Frankel-Rose

Crisis dummy variables $=1$ if crisis in period $t,=0$ otherwise. A dash (-) denotes countries not included in dataset. 


\section{Table 3}

\section{Agreement Between Crisis Dating Systems}

\section{Latin America}

Argentina

Brazil

Chile

Colombia

Ecuador

Mexico

Peru

Uruguay

Venezuela

\section{East Asia}

China

Indonesia

Malaysia

Korea

Philippines

Taiwan

Thailand

\section{Other \\ Egypt \\ Hungary \\ India \\ Israel \\ Morocco \\ Pakistan \\ Poland \\ Saudi Arabia \\ South Africa \\ Turkey}

All Countries

Correlation Coefficient
Percentage of Crises Commonly Identified

$\begin{array}{rrr}\text { KSS v KLR } & \text { KSS v FR } & \text { KLR v FR } \\ 67 & 25 & 0 \\ 73 & 0 & 0 \\ 50 & 80 & 67 \\ 80 & 50 & 67 \\ - & - & - \\ 67 & 75 & 67 \\ 67 & 25 & 29 \\ 40 & 86 & 50 \\ 67 & 91 & 60\end{array}$

$\begin{array}{rrr}- & - & - \\ 100 & 100 & 100 \\ 33 & 33 & 100 \\ 80 & 80 & 100 \\ 89 & 57 & 67 \\ - & - & - \\ 29 & 29 & 100\end{array}$

Notes:

KSS: Kamin-Schindler-Samuel

KLR: Kaminsky-Lizondo-Reinhart

FR: Frankel-Rose 
Table 4

Explanatory Variables: Basic Statistics

(percent)

\begin{tabular}{lcccc}
\hline & \multicolumn{2}{c}{ Mean Averages } & \multicolumn{2}{c}{ Median Averages } \\
& $\begin{array}{c}\text { Non-Crisis } \\
\text { Years }\end{array}$ & Crisis Years & $\begin{array}{c}\text { Non-Crisis } \\
\text { Years }\end{array}$ & Crisis Years \\
\hline Real GDP growth (L) & -0.11 & -0.75 & 0.38 & -0.54 \\
Deficit/GDP (L) & 2.62 & 4.01 & 2.40 & 4.10 \\
Domestic bank loans/GDP (L) & 22.82 & 15.98 & 10.43 & 11.71 \\
M2/reserves (L) & 5.20 & 41.19 & -4.91 & 20.77 \\
Total external debt/exports (L) & 99.28 & 106.34 & 94.43 & 101.55 \\
Reserves/Short-term debt (L) & 98.96 & 83.80 & 89.98 & 78.77 \\
Real effective exchange rate (L) & -3.00 & 8.47 & -6.12 & 5.67 \\
Export growth (L) & -1.63 & -4.01 & -1.73 & -3.90 \\
Current account/GDP (L) & -1.65 & -3.62 & -1.98 & -3.43 \\
Foreign direct investment/GDP & 1.42 & 1.18 & 0.75 & 0.71 \\
(L) & & & & -1.81 \\
Terms of trade growth & 0.76 & -2.69 & 0.36 & 4.29 \\
U.S. real interest rate & 3.18 & 3.81 & 3.20 & -0.60 \\
Industrial country GDP growth & 0.00 & -0.17 & -0.10 & \\
\hline
\end{tabular}

(L) indicates lagged by one year. 
Table 5

Bivariate Probit Regression Results

Dependent Variable: Crisis Dummy

\begin{tabular}{lcccc}
\hline & $(1)$ & $(2)$ & $(3)$ & $(4)$ \\
Explanatory Variable: & dProb/dx & z-stat & P > 1z1 & Pseudo R $^{2}$ \\
\hline Real GDP growth (L) & -0.49 & -1.27 & 0.205 & 0.00 \\
Deficit/GDP (L) & 0.84 & 2.34 & 0.019 & 0.01 \\
Domestic bank loans/GDP (L) & -0.03 & -0.80 & 0.421 & 0.00 \\
M2/reserves (L) & 0.10 & 4.17 & 0.000 & 0.03 \\
Total external debt/exports (L) & 0.13 & 2.14 & 0.032 & 0.01 \\
Reserves/Short-term debt (L) & -0.08 & -2.28 & 0.022 & 0.01 \\
Real effective exchange rate (L) & 0.3 & 4.36 & 0.000 & 0.04 \\
Export growth (L) & -0.13 & -1.23 & 0.219 & 0.00 \\
Current account/GDP (L) & -1.47 & -3.56 & 0.000 & 0.03 \\
Foreign direct investment/GDP & -1.58 & -1.27 & 0.204 & 0.00 \\
(L) & & & & 0.01 \\
Terms of trade growth & -0.35 & -2.23 & 0.026 & 0.02 \\
U.S. real interest rate & 3.19 & 3.18 & 0.001 & 0.00 \\
Industrial country GDP growth & -1.72 & -1.22 & 0.222 & $1981-$
\end{tabular}

Note: Probit regression of selected indicators on 0/1 crisis dummy for twenty-six countries in 19811999. dProb/dx coefficients represent the change in probability (0-100 percent) of a crisis caused by a one-unit change in the explanatory variable. (L) indicates lagged by one year. $\mathrm{P}>1 \mathrm{z} 1$ is estimated probability that coefficient is actually equal to zero. 
Table $6 a$

Broad Regression Results

Dependent Variable: Crisis Dummy

\begin{tabular}{|c|c|c|c|c|}
\hline & (1) & (2) & (3) & (4) \\
\hline & All Countries & $\begin{array}{l}\text { Latin } \\
\text { America }\end{array}$ & Asia & Other \\
\hline Pseudo $\mathrm{R}^{2}$ & 0.15 & 0.28 & 0.31 & 0.23 \\
\hline Number of Observations & 350 & 145 & 109 & 96 \\
\hline Real GDP growth (L) & $\begin{array}{l}-0.13 \\
(-0.26)\end{array}$ & $\begin{array}{c}-.21 \\
(-0.34)\end{array}$ & $\begin{array}{c}0.98 \\
(0.86)\end{array}$ & $\begin{array}{l}2.53 \\
(2.11)\end{array}$ \\
\hline Deficit/GDP (L) & $\begin{array}{c}0.28 \\
(0.61)\end{array}$ & $\begin{array}{c}-0.17 \\
(-0.18)\end{array}$ & $\begin{array}{c}0.02 \\
(0.01)\end{array}$ & $\begin{array}{c}1.70 \\
(1.81)\end{array}$ \\
\hline Domestic bank loans/GDP (L) & $\begin{array}{l}-0.05 \\
(-0.78)\end{array}$ & $\begin{array}{l}-0.11 \\
(-1.38)\end{array}$ & $\begin{array}{c}0.10 \\
(0.54)\end{array}$ & $\begin{array}{c}0.05 \\
(0.28)\end{array}$ \\
\hline M2/reserves (L) & $\begin{array}{c}0.07 \\
(2.00)\end{array}$ & $\begin{array}{c}0.14 \\
(2.65)\end{array}$ & $\begin{array}{c}0.16 \\
(1.83)\end{array}$ & $\begin{array}{l}-0.12 \\
(-1.78)\end{array}$ \\
\hline Total external debt/exports (L) & $\begin{array}{c}0.04 \\
(0.48)\end{array}$ & $\begin{array}{l}-0.06 \\
(-0.39)\end{array}$ & $\begin{array}{c}-0.04 \\
(-0.20)\end{array}$ & $\begin{array}{c}0.14 \\
(0.76)\end{array}$ \\
\hline Reserves/Short-term debt (L) & $\begin{array}{c}0.02 \\
(0.32)\end{array}$ & $\begin{array}{l}-0.03 \\
(-0.35)\end{array}$ & $\begin{array}{c}-0.02 \\
(-0.10)\end{array}$ & $\begin{array}{c}0.01 \\
(0.18)\end{array}$ \\
\hline Real effective exchange rate (L) & $\begin{array}{c}0.38 \\
(3.37)\end{array}$ & $\begin{array}{c}0.64 \\
(3.61)\end{array}$ & $\begin{array}{c}-0.03 \\
(-0.13)\end{array}$ & $\begin{array}{c}0.21 \\
(0.92)\end{array}$ \\
\hline Export growth (L) & $\begin{array}{c}-0.18 \\
(-1.25)\end{array}$ & $\begin{array}{c}0.13 \\
(0.63)\end{array}$ & $\begin{array}{c}-1.11 \\
(-2.67)\end{array}$ & $\begin{array}{c}-0.17 \\
(-0.67)\end{array}$ \\
\hline Current account/GDP (L) & $\begin{array}{c}-0.80 \\
(-1.44)\end{array}$ & $\begin{array}{c}-1.64 \\
(-1.48)\end{array}$ & $\begin{array}{c}0.09 \\
(0.09)\end{array}$ & $\begin{array}{l}-3.61 \\
(-2.71)\end{array}$ \\
\hline $\begin{array}{l}\text { Foreign direct investment/GDP } \\
\text { (L) }\end{array}$ & $\begin{array}{l}-0.95 \\
(-0.58)\end{array}$ & $\begin{array}{l}-3.80 \\
(-1.34)\end{array}$ & $\begin{array}{c}0.87 \\
(0.30)\end{array}$ & $\begin{array}{l}-4.08 \\
(-1.12)\end{array}$ \\
\hline Terms of trade growth & $\begin{array}{c}-0.43 \\
(-2.46)\end{array}$ & $\begin{array}{c}-0.33 \\
(-1.23)\end{array}$ & $\begin{array}{c}-1.17 \\
(-2.50)\end{array}$ & $\begin{array}{c}-0.26 \\
(-0.97)\end{array}$ \\
\hline U.S. real interest rate & $\begin{array}{c}2.38 \\
(1.42)\end{array}$ & $\begin{array}{c}0.80 \\
(0.28)\end{array}$ & $\begin{array}{c}7.74 \\
(2.01)\end{array}$ & $\begin{array}{c}-1.48 \\
(-0.50)\end{array}$ \\
\hline Industrial country GDP growth & $\begin{array}{l}-5.26 \\
(-2.65)\end{array}$ & $\begin{array}{l}-1.77 \\
(-0.59)\end{array}$ & $\begin{array}{c}-10.16 \\
(-2.42)\end{array}$ & $\begin{array}{l}-8.26 \\
(-2.12)\end{array}$ \\
\hline
\end{tabular}

Note: Probit regression of selected indicators on 0/1 crisis dummy for twenty-six countries in 19811999. Dprob/dx coefficients represent the change in probability (0-100 percent) of a crisis caused by a one-unit change in the explanatory variable. (L) indicates lagged by one year. Numbers in parentheses are z-statistics. 
Table $6 b$

Boiled-down Regression Results

Dependent Variable: Crisis Dummy

\begin{tabular}{|c|c|c|c|c|}
\hline & (1) & (2) & (3) & (4) \\
\hline & All Countries & Latin America & Asia & Other \\
\hline Pseudo $\mathrm{R}^{2}$ & 0.10 & 0.24 & 0.27 & 0.11 \\
\hline Number of Observations & 417 & 154 & 116 & 179 \\
\hline \multicolumn{5}{|l|}{ Real GDP Growth (L) } \\
\hline Deficit/GDP (L) & $\begin{array}{c}0.69 \\
(1.78)\end{array}$ & & & $\begin{array}{c}1.01 \\
(2.27)\end{array}$ \\
\hline Domestic bank loans/GDP (L) & & $\begin{array}{l}-0.10 \\
(-1.44)\end{array}$ & & \\
\hline M2/reserves (L) & $\begin{array}{c}0.06 \\
(2.39)\end{array}$ & $\begin{array}{c}0.14 \\
(3.05)\end{array}$ & $\begin{array}{c}0.19 \\
(2.73)\end{array}$ & \\
\hline Total external debt/exports (L) & & & & $\begin{array}{c}0.24 \\
(2.37)\end{array}$ \\
\hline \multicolumn{5}{|l|}{ Reserves/Short-term debt (L) } \\
\hline Real effective exchange rate (L) & $\begin{array}{c}0.30 \\
(3.43)\end{array}$ & $\begin{array}{c}0.54 \\
(3.34)\end{array}$ & & \\
\hline Export growth (L) & & & $\begin{array}{l}-0.87 \\
(-2.80)\end{array}$ & \\
\hline Current account/GDP (L) & $\begin{array}{l}-1.21 \\
(-2.57)\end{array}$ & $\begin{array}{l}-1.17 \\
(-1.21)\end{array}$ & & $\begin{array}{l}-1.80 \\
(-2.63)\end{array}$ \\
\hline \multicolumn{5}{|l|}{$\begin{array}{l}\text { Foreign direct investment/GDP } \\
\text { (L) }\end{array}$} \\
\hline Change in terms of trade & $\begin{array}{l}-0.35 \\
(-2.19)\end{array}$ & $\begin{array}{c}-0.36 \\
(-1.45)\end{array}$ & $\begin{array}{l}-1.20 \\
(-2.66)\end{array}$ & \\
\hline Change in U.S. real interest rate & & $\begin{array}{c}3.81 \\
(1.61)\end{array}$ & $\begin{array}{c}4.96 \\
(1.97)\end{array}$ & \\
\hline Industrial country GDP growth & $\begin{array}{c}-4.29 \\
(-2.58)\end{array}$ & & $\begin{array}{l}-7.10 \\
(-2.04)\end{array}$ & $\begin{array}{r}-3.70 \\
(-1.46)\end{array}$ \\
\hline
\end{tabular}

Note: Probit regression of selected indicators on 0/1 crisis dummy for twenty-six countries in 19811999. Dprob/dx coefficients represent the change in probability (0-100 percent) of a crisis caused by a one-unit change in the explanatory variable. (L) indicates lagged by one year. Numbers in parentheses are z-statistics. 
Table 6c

Broad Regression Results: All countries*

Dependent Variable: Crisis Dummy

\begin{tabular}{|c|c|c|c|}
\hline & $\begin{array}{c}(1) \\
\text { KSS Crisis Dates } \\
\end{array}$ & $\begin{array}{c}(2) \\
\text { KLR Crisis Dates } \\
\end{array}$ & $\begin{array}{c}\text { (3) } \\
\text { FR Crisis Dates } \\
\end{array}$ \\
\hline Pseudo $\mathrm{R}^{2}$ & 0.21 & 0.14 & 0.15 \\
\hline Number of Observations & 265 & 265 & 265 \\
\hline Real GDP growth (L) & $\begin{array}{c}-0.18 \\
(-0.34)\end{array}$ & $\begin{array}{c}-0.17 \\
(-0.50)\end{array}$ & $\begin{array}{c}1.12 \\
(2.58)\end{array}$ \\
\hline Deficit/GDP (L) & $\begin{array}{c}0.17 \\
(0.26)\end{array}$ & $\begin{array}{c}-0.03 \\
(-0.07)\end{array}$ & $\begin{array}{c}-0.41 \\
(-0.82)\end{array}$ \\
\hline Domestic bank loans/GDP (L) & $\begin{array}{c}-0.08 \\
(-1.19)\end{array}$ & $\begin{array}{c}-0.06 \\
(-1.20)\end{array}$ & $\begin{array}{c}-0.08 \\
(-1.51)\end{array}$ \\
\hline M2/reserves (L) & $\begin{array}{c}0.11 \\
(2.69)\end{array}$ & $\begin{array}{c}0.05 \\
(1.94)\end{array}$ & $\begin{array}{c}0.01 \\
(0.45)\end{array}$ \\
\hline Total external debt/exports (L) & $\begin{array}{c}-0.02 \\
(-0.15)\end{array}$ & $\begin{array}{c}-0.01 \\
(-0.11)\end{array}$ & $\begin{array}{c}-0.12 \\
(-1.50)\end{array}$ \\
\hline Reserves/Short-term debt (L) & $\begin{array}{c}0.01 \\
(0.23)\end{array}$ & $\begin{array}{c}-0.01 \\
(-0.33)\end{array}$ & $\begin{array}{c}0.00 \\
(0.04)\end{array}$ \\
\hline Real effective exchange rate $(\mathrm{L})$ & $\begin{array}{c}0.33 \\
(2.35)\end{array}$ & $\begin{array}{c}0.18 \\
(1.92)\end{array}$ & $\begin{array}{c}0.25 \\
(2.38)\end{array}$ \\
\hline Export growth (L) & $\begin{array}{c}-0.21 \\
(-1.29)\end{array}$ & $\begin{array}{c}-0.12 \\
(-1.14)\end{array}$ & $\begin{array}{c}-0.14 \\
(-1.22)\end{array}$ \\
\hline Current account/GDP (L) & $\begin{array}{c}-1.83 \\
(-2.69)\end{array}$ & $\begin{array}{c}-0.59 \\
(-1.14)\end{array}$ & $\begin{array}{c}-1.45 \\
(-2.18)\end{array}$ \\
\hline Foreign direct investment/GDP (L) & $\begin{array}{c}-1.15 \\
(-0.63)\end{array}$ & $\begin{array}{c}-0.21 \\
(-0.19)\end{array}$ & $\begin{array}{c}-4.67 \\
(-2.63)\end{array}$ \\
\hline Terms of trade growth & $\begin{array}{c}-0.59 \\
(-2.95)\end{array}$ & $\begin{array}{c}-0.26 \\
(-2.04)\end{array}$ & $\begin{array}{c}-0.11 \\
(-0.75)\end{array}$ \\
\hline U.S. real interest rate & $\begin{array}{c}2.45 \\
(1.29)\end{array}$ & $\begin{array}{c}-0.40 \\
(-0.32)\end{array}$ & $\begin{array}{c}0.68 \\
(0.53)\end{array}$ \\
\hline Industrial country GDP growth & $\begin{array}{c}-4.80 \\
(-2.17)\end{array}$ & $\begin{array}{c}-1.30 \\
(-0.94)\end{array}$ & $\begin{array}{c}-0.88 \\
(-0.58)\end{array}$ \\
\hline
\end{tabular}

Note: Probit regression of selected indicators on 0/1 crisis dummy for twenty-six countries in 19811999. Dprob/dx coefficients represent the change in probability (0-100 percent) of a crisis caused by a one-unit change in the explanatory variable. (L) indicates lagged by one year. Numbers in parentheses are z-statistics.

*Regressions estimated for all countries shared in common by KSS, KLR, and FR datasets. 
Based on Broad All-Country Regression

$\begin{array}{cc}\text { Avg. in } & \text { Avg. in } \\ \text { non-crisis } & \text { crisis } \\ \text { years } & \text { years }\end{array}$

(1) (2)
Contributions in crisis years domestic

(3) external

balance

(4)

\section{external}

shocks

(5)
$\Delta$ contribution: non-crisis to crisis years domestic

(6) external

(7) external shocks

(8)

Latin America

\begin{tabular}{|c|c|c|c|c|c|c|c|c|}
\hline Argentina & 0.186 & 0.360 & 0.231 & 0.119 & 0.009 & 0.013 & 0.139 & 0.023 \\
\hline Brazil & 0.205 & 0.314 & 0.248 & 0.019 & 0.047 & 0.017 & 0.040 & 0.053 \\
\hline Chile & 0.150 & 0.552 & 0.230 & 0.220 & 0.101 & 0.030 & 0.242 & 0.130 \\
\hline Colombia & 0.174 & 0.447 & 0.292 & 0.102 & 0.053 & 0.096 & 0.115 & 0.063 \\
\hline Ecuador & 0.116 & 0.490 & 0.261 & 0.154 & 0.075 & 0.049 & 0.228 & 0.098 \\
\hline Mexico & 0.208 & 0.396 & 0.222 & 0.103 & 0.072 & 0.000 & 0.117 & 0.071 \\
\hline Peru & 0.247 & 0.192 & 0.404 & -0.162 & -0.050 & 0.191 & -0.196 & -0.051 \\
\hline Uruguay & 0.128 & 0.378 & 0.232 & 0.036 & 0.109 & 0.018 & 0.104 & 0.127 \\
\hline Venezuela & 0.197 & 0.346 & 0.233 & 0.076 & 0.037 & 0.040 & 0.064 & 0.044 \\
\hline Median & 0.186 & 0.378 & 0.233 & 0.102 & 0.053 & 0.030 & 0.115 & 0.063 \\
\hline \multicolumn{9}{|l|}{ East Asia } \\
\hline China & 0.214 & 0.234 & 0.192 & 0.016 & 0.026 & 0.025 & 0.039 & -0.045 \\
\hline Indonesia & 0.114 & 0.343 & 0.220 & 0.018 & 0.106 & 0.021 & 0.087 & 0.121 \\
\hline Malaysia & 0.191 & 0.400 & 0.200 & 0.102 & 0.098 & 0.007 & 0.095 & 0.107 \\
\hline Korea & 0.148 & 0.442 & 0.211 & 0.104 & 0.127 & 0.025 & 0.097 & 0.172 \\
\hline Philippines & 0.208 & 0.454 & 0.348 & 0.083 & 0.022 & 0.140 & 0.097 & 0.009 \\
\hline Taiwan & 0.120 & 0.195 & 0.150 & 0.017 & 0.028 & 0.001 & 0.026 & 0.048 \\
\hline Thailand & 0.172 & 0.381 & 0.226 & 0.063 & 0.093 & 0.028 & 0.065 & 0.117 \\
\hline Median & 0.172 & 0.381 & 0.211 & 0.063 & 0.093 & 0.025 & 0.087 & 0.107 \\
\hline \multicolumn{9}{|l|}{ Other } \\
\hline Egypt & 0.248 & 0.377 & 0.197 & 0.189 & -0.009 & -0.008 & 0.179 & -0.042 \\
\hline Hungary & 0.133 & - & 0.181 & 0.031 & - & 0.003 & -0.054 & - \\
\hline India & 0.061 & 0.230 & 0.311 & -0.214 & 0.134 & 0.081 & -0.096 & 0.184 \\
\hline Israel & 0.182 & 0.367 & 0.264 & -0.004 & 0.107 & 0.051 & 0.001 & 0.133 \\
\hline Morocco & 0.371 & 0.423 & 0.319 & 0.172 & -0.068 & 0.025 & 0.141 & -0.114 \\
\hline Pakistan & 0.234 & 0.375 & 0.283 & 0.032 & 0.059 & 0.009 & 0.040 & 0.091 \\
\hline Poland & 0.164 & - & - & - & - & - & - & - \\
\hline Saudi Arabia & 0.233 & 0.455 & 0.234 & 0.166 & 0.055 & -0.005 & 0.151 & 0.076 \\
\hline South Africa & 0.187 & 0.122 & 0.165 & -0.001 & -0.041 & -0.022 & -0.009 & -0.034 \\
\hline Turkey & 0.239 & 0.224 & 0.197 & 0.087 & -0.060 & 0.001 & 0.104 & -0.121 \\
\hline Median* & 0.234 & 0.371 & 0.249 & 0.060 & 0.023 & 0.005 & 0.072 & 0.021 \\
\hline Overall Median* & 0.189 & 0.376 & 0.231 & 0.079 & 0.054 & 0.023 & 0.096 & 0.067 \\
\hline
\end{tabular}


Table $7 \mathrm{~b}$

Average Simulated Crisis Probabilities

Based on Broad Regional Regressions

\begin{tabular}{|c|c|c|c|c|c|c|c|}
\hline Avg. in & Avg. in & Cont & tions in $c$ & years & $\Delta$ contrib & non-cris & risis years \\
\hline non-crisis & crisis & domestic & external & external & domestic & external & external \\
\hline & years & & bal & sho & & balar & sh \\
\hline (1) & (2) & (3) & (4) & (5) & (6) & (7) & (8) \\
\hline
\end{tabular}

Latin America

Argentina

$0.217 \quad 0.403$

0.238

0.241

$-0.076$

0.042

0.235

$-0.091$

Brazil

0.169

0.325

0.288

0.010

0.028

0.102

0.032

0.022

Chile

0.160

0.125

0.389

0.047

$-0.032$

0.396

0.037

Colombia

0.169

0.578

0.330

0.176

0.072

0.126

0.195

0.087

Ecuador

0.113

0.277

0.225

0.098

0.089

0.314

0.084

Mexico

0.212

0.216

0.185

0.026

0.018

0.186

0.011

Peru

0.267

0.318

0.575

$-0.230$

$-0.026$

0.343

$-0.257$

$-0.034$

Uruguay

0.152

0.418

0.251

0.107

0.060

0.032

0.190

0.045

Venezuela

0.242

0.199

0.182

0.032

0.029

0.107

0.035

Median

0.169

0.418

0.251

0.182

0.032

0.042

0.190

0.035

East Asia

China

Indonesia

Malaysia

Korea

Philippines

Taiwan

Thailand

Median

0.215

0.238

0.250

0.031

$-0.043$

0.256

$-0.024$

0.279

0.198

0.043

0.170

0.240

0.301

0.427

0.108

0.221

0.122

0.236

0.071

0.078

0.219

0.226

0.498

0.240

0.498

0.250

0.049

0.230

0.049

0.221

Other

0.064
Egypt

Hungary

India

Israel

Morocco

Pakistan

Poland

Saudi Arabia

South Africa

Turkey

Median*

Overall Median*
0.126

0.450

0.285

0.163

0.261

0.288

0.091

0.197

0.116

0.213

0.213

0.217
0.447

0.252

0.131

$-0.022$

0.037

0.205

0.138

0.365

0.209

0.358

0.507

0.206

0.371

0.371

0.020

0.172

0.418

0.013

0.184

0.053

0.205

0.426

0.238

0.107

0.150

0.111

0.060

$-0.014$

$-0.276$

0.028

0.029

0.076

0.105

$-0.001$

$-0.028$

0.019

0.114

0.344

$-0.125$

0.012

0.001

0.056

* Not including Poland. 
Table $7 \mathrm{c}$

\section{Average Simulated Crisis Probabilities}

Based on Boiled All-Country Regression

\begin{tabular}{cccccccc} 
Avg. in & Avg. in & \multicolumn{3}{c}{ Contributions in crisis years } & \multicolumn{4}{c}{ contribution: non-crisis to crisis years } \\
non-crisis & crisis & domestic & external & external & domestic & external & external \\
years & years & & balance & shocks & & balance & shocks \\
$(1)$ & $(2)$ & $(3)$ & $(4)$ & $(5)$ & $(6)$ & (7) & (8)
\end{tabular}

Latin America

\begin{tabular}{|c|c|c|c|c|c|c|c|c|}
\hline Argentina & 0.188 & 0.356 & 0.250 & 0.106 & 0.000 & 0.029 & 0.125 & 0.015 \\
\hline Brazil & 0.203 & 0.321 & 0.254 & 0.022 & 0.045 & 0.024 & 0.028 & 0.066 \\
\hline Chile & 0.173 & 0.464 & 0.263 & 0.172 & 0.030 & 0.050 & 0.188 & 0.053 \\
\hline Colombia & 0.164 & 0.432 & 0.300 & 0.121 & 0.011 & 0.106 & 0.143 & 0.019 \\
\hline Ecuador & 0.156 & 0.385 & 0.272 & 0.113 & 0.000 & 0.046 & 0.172 & 0.010 \\
\hline Mexico & 0.212 & 0.377 & 0.247 & 0.095 & 0.036 & 0.017 & 0.109 & 0.039 \\
\hline Peru & 0.267 & 0.207 & 0.383 & -0.131 & -0.045 & 0.149 & -0.155 & -0.053 \\
\hline Uruguay & 0.186 & 0.269 & 0.221 & 0.019 & 0.028 & 0.023 & 0.023 & 0.037 \\
\hline Venezuela & 0.157 & 0.257 & 0.194 & 0.068 & -0.006 & 0.034 & 0.054 & 0.011 \\
\hline Median & 0.186 & 0.356 & 0.254 & 0.095 & 0.011 & 0.034 & 0.109 & 0.019 \\
\hline \multicolumn{9}{|l|}{ East Asia } \\
\hline China & 0.233 & 0.179 & 0.182 & 0.073 & -0.076 & 0.023 & 0.070 & -0.148 \\
\hline Indonesia & 0.192 & 0.343 & 0.221 & 0.133 & -0.011 & 0.025 & 0.135 & -0.010 \\
\hline Malaysia & 0.159 & 0.324 & 0.178 & 0.105 & 0.040 & 0.013 & 0.097 & 0.055 \\
\hline Korea & 0.194 & 0.402 & 0.258 & 0.075 & 0.070 & 0.031 & 0.070 & 0.107 \\
\hline Philippines & 0.219 & 0.378 & 0.344 & 0.053 & -0.020 & 0.127 & 0.061 & -0.030 \\
\hline Taiwan & 0.107 & 0.162 & 0.129 & 0.014 & 0.019 & 0.020 & 0.012 & 0.023 \\
\hline Thailand & 0.171 & 0.303 & 0.207 & 0.048 & 0.047 & 0.015 & 0.053 & 0.063 \\
\hline Median & 0.192 & 0.324 & 0.207 & 0.073 & 0.019 & 0.023 & 0.070 & 0.023 \\
\hline \multicolumn{9}{|l|}{ Other } \\
\hline Egypt & 0.237 & 0.342 & 0.191 & 0.159 & -0.008 & -0.027 & 0.150 & -0.018 \\
\hline Hungary & 0.195 & 0.205 & 0.204 & 0.010 & -0.008 & -0.017 & -0.005 & 0.032 \\
\hline India & 0.253 & 0.331 & 0.297 & -0.044 & 0.079 & 0.067 & -0.077 & 0.087 \\
\hline Israel & 0.271 & 0.502 & 0.409 & 0.025 & 0.068 & 0.140 & 0.027 & 0.063 \\
\hline Morocco & 0.277 & 0.257 & 0.276 & 0.070 & -0.089 & 0.011 & 0.069 & -0.101 \\
\hline Pakistan & 0.244 & 0.327 & 0.286 & 0.017 & 0.024 & 0.008 & 0.026 & 0.049 \\
\hline Poland & 0.180 & 0.057 & 0.161 & -0.093 & -0.011 & -0.010 & -0.127 & 0.014 \\
\hline Saudi Arabia & 0.198 & 0.429 & 0.177 & 0.212 & 0.041 & -0.048 & 0.241 & 0.038 \\
\hline South Africa & 0.197 & 0.118 & 0.155 & -0.007 & -0.030 & -0.025 & -0.013 & -0.042 \\
\hline Turkey & 0.219 & 0.186 & 0.180 & 0.067 & -0.061 & -0.008 & 0.079 & -0.104 \\
\hline Median & 0.228 & 0.292 & 0.197 & 0.021 & -0.008 & -0.009 & 0.026 & 0.023 \\
\hline
\end{tabular}

Overall Median

0.196

0.325

$\begin{array}{lll}0.234 & 0.067 \quad 0.006\end{array}$

$0.023 \quad 0.065$

0.021 
Table 7d

\section{Average Simulated Crisis Probabilities}

Based on Boiled Regional Regression

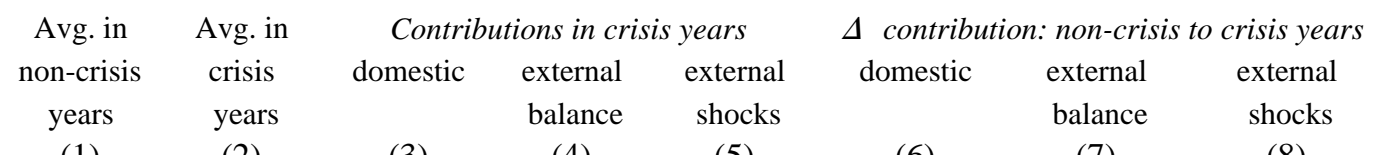
(1)
(2)
(3)
(4)
(5)
(6)
(7)
(8)

\section{Latin America}

Argentina

Brazil

Chile

Colombia

Ecuador

Mexico

Peru

Uruguay

Venezuela

Median

East Asia

China

Indonesia

Malaysia

Korea

Philippines

Taiwan

Thailand

Median

Other

Egypt

Hungary

India

Israel

Morocco

Pakistan

Poland

Saudi Arabia

South Africa

Turkey

Median

Overall Median
$0.212 \quad 0.312$

0.162

0.315

0.201

0.578

0.175

0.112

0.639

0.569

0.233

0.403

0.257

0.313

0.218

0.343

0.243

0.398

0.212

0.398

0.210

0.174

$-0.072$

0.024

0.179

0.026

0.078

0.050

$-0.103$

$0.203 \quad 0.233$

0.142

0.004

0.244

0.134

0.184

0.245

0.141

$-0.271$

0.004

0.075

0.141

0.072

0.220

0.139

$0.245 \quad 0.014$

$-0.056$

0.046

$-0.006$

0.253

0.080

$-0.062$

$-0.092$

$0.221 \quad 0.461$

0.281

$-0.074$

0.150

0.015

0.018

0.222

$0.222 \quad 0.385$

0.234

0.634

0.267

0.149

0.218

0.095

0.087

0.105

0.287

0.069

0.026

0.032

0.026

0.150

0.085

0.080

0.046

0.461

0.251

0.374

$0.329 \quad-0.001$

0.046

0.175

$-0.015$

0.048

$0.210 \quad 0.213$

$0.237 \quad-0.037$

0.013

0.040

$-0.050$

0.013

$0.184 \quad 0.297$

0.248

0.006

0.042

0.064

0.006

0.042

$0.229 \quad 0.503$

$0.468 \quad 0.045$

$-0.010$

0.244

0.050

$-0.021$

$0.228 \quad 0.286$

$0.251 \quad 0.072$

$-0.037$

0.021

0.059

$-0.021$

$0.250 \quad 0.250$

0.219

0.012

0.019

$-0.019$

0.016

0.004

$0.116 \quad 0.187$

0.201

$-0.039$

0.025

0.070

$-0.030$

0.031

$\begin{array}{ll}0.168 & 0.279\end{array}$

0.066

0.196

0.017

0.157

0.000

$-0.018$

0.117

0.139

0.174

0.237

0.225

0.049

$-0.037$

$-0.074$

0.169

0.017

0.179

0.265

0.231

0.009

0.015

0.032

0.009

$-0.018$

0.051

0.039

$-0.027$

0.045

0.013

0.009 
Table 7e

\section{Average Simulated Crisis Probabilities}

Based on Broad All-Country Regression Using KLR Dating System

$\begin{array}{cc}\text { Avg. in } & \text { Avg. in } \\ \text { non-crisis } & \text { crisis } \\ \text { years } & \text { years }\end{array}$

(1) (2)
Contributions in crisis years domestic external external

(3) balance shocks

(4)
(5)
$\Delta$ contribution: non-crisis to crisis years domestic

(6) external balance

(7) external shocks

(8)

\section{Latin America}

$\begin{array}{lccccccccr}\text { Argentina } & 0.073 & 0.146 & 0.106 & -0.019 & 0.059 & 0.026 & -0.039 & 0.086 \\ \text { Brazil } & 0.086 & 0.152 & 0.089 & 0.036 & 0.027 & -0.005 & 0.052 & 0.019 \\ \text { Chile } & 0.092 & 0.176 & 0.071 & 0.078 & 0.027 & -0.019 & 0.068 & 0.035 \\ \text { Colombia } & 0.086 & 0.299 & 0.142 & 0.015 & 0.142 & 0.055 & -0.017 & 0.175 \\ \text { Ecuador** } & - & - & - & - & - & - & - & - \\ \text { Mexico } & 0.088 & 0.244 & 0.066 & 0.139 & 0.039 & -0.022 & 0.141 & 0.037 \\ \text { Peru } & 0.111 & 0.057 & 0.148 & -0.046 & -0.046 & 0.037 & -0.042 & -0.049 \\ \text { Uruguay } & 0.049 & - & 0.139 & - & - & 0.052 & - & - \\ \text { Venezuela } & 0.077 & 0.209 & 0.108 & 0.073 & 0.028 & 0.037 & 0.048 & 0.047 \\ \text { Median } & 0.086 & 0.176 & 0.107 & 0.036 & 0.028 & 0.031 & 0.048 & 0.037\end{array}$

East Asia

China**

Indonesia

Malaysia

Korea

Philippines

Taiwan**

Thailand

Median

0.123

0.078

0.062

$-0.017$

$-0.013$

0.043

$-0.006$

0.095

0.143

0.096

$0.025-0.008$

0.027

0.030

0.002

Other

Egypt**

Hungary**

India

0.060

0.033

0.277

$-0.244$

$-0.001$

0.194

$-0.193$

$-0.029$

Israel

0.091

Morocco**

Pakistan

0.128

Poland**

Saudi Arabia**

South Africa

0.075

0.035

0.005

$0.072 \quad 0.026$

$-0.025$

0.002

Turkey

0.088

- $\quad 0.072$

0.006

0.021

Median*

0.075

0.033

0.072

0.005

$-0.001$

0.006

0.002

$-0.029$

Overall Median*

0.086

0.151

$0.101 \quad 0.025$

0.027

0.027

0.021

0.019

** Not included in the estimation data set. 
Table $7 \mathrm{f}$

Average Simulated Crisis Probabilities

Based on Broad All-Country Regression Using FR Dating System

Avg. in Avg. in Contributions in crisis years non-crisis crisis years years

(1)
(2) domestic

(3) external external

balance shocks

(4)
$\Delta$ contribution: non-crisis to crisis years domestic

(6) external
balance

(7) external

shocks

(8)

\section{Latin America}

$\begin{array}{lcccccccc}\text { Argentina } & 0.129 & 0.247 & 0.179 & 0.244 & -0.176 & 0.038 & 0.261 & -0.181 \\ \text { Brazil } & 0.129 & 0.165 & 0.176 & -0.012 & 0.001 & 0.047 & -0.013 & 0.002 \\ \text { Chile } & 0.074 & 0.559 & 0.044 & 0.448 & 0.067 & -0.071 & 0.471 & 0.085 \\ \text { Colombia } & 0.117 & 0.195 & 0.115 & 0.019 & 0.061 & 0.015 & -0.008 & 0.071 \\ \text { Ecuador** } & - & - & - & - & - & - & - & - \\ \text { Mexico } & 0.103 & 0.265 & 0.169 & 0.070 & 0.026 & 0.063 & 0.076 & 0.022 \\ \text { Peru } & 0.123 & 0.274 & 0.250 & 0.019 & 0.005 & 0.127 & 0.022 & 0.002 \\ \text { Uruguay } & 0.147 & 0.174 & 0.077 & 0.069 & 0.028 & -0.097 & 0.099 & 0.025 \\ \text { Venezuela } & 0.131 & 0.174 & 0.072 & 0.091 & 0.010 & -0.030 & 0.070 & 0.003 \\ \text { Median } & 0.126 & 0.221 & 0.142 & 0.069 & 0.018 & 0.026 & 0.073 & 0.013\end{array}$

East Asia

China**

Indonesia

0.042

0.188

0.110

0.040

0.038

$-0.013$

0.113

0.046

Malaysia

0.162

0.230

0.150

0.087

$-0.006$

0.008

0.066

$-0.006$

Korea

0.040

0.051

0.049

0.002

0.001

0.021

$-0.006$

$-0.004$

Philippines

0.129

0.318

0.136

0.174

0.009

$-0.002$

0.179

0.011

Taiwan**

Thailand

0.176

$0.225 \quad 0.097$

0.136

$-0.008$

$-0.038$

0.085

0.002

Median

0.129

0.225

$0.110 \quad 0.087$

0.001

$-0.002$

0.085

0.002

Other

\section{Egypt**}

Hungary**

India

0.069

0.135

Israel

0.164

Morocco**

Pakistan

0.160

0.568

0.196

0.307

0.065

0.017

0.310

0.080

Poland**

Saudi Arabia

South Africa

0.133

0.127

0.120

$-0.031$

0.038

$-0.001$

$-0.042$

0.036

Turkey

0.153

0.279

0.210

0.029

0.040

0.080

0.025

0.020

Median*

0.153

0.279

0.196

0.029

0.040

0.017

0.025

0.036

$$
0.129
$$

0.228

0.128

0.069

0.018

0.012

0.073

0.016

*Not including India and Israel.

** Not included in the estimation data set. 


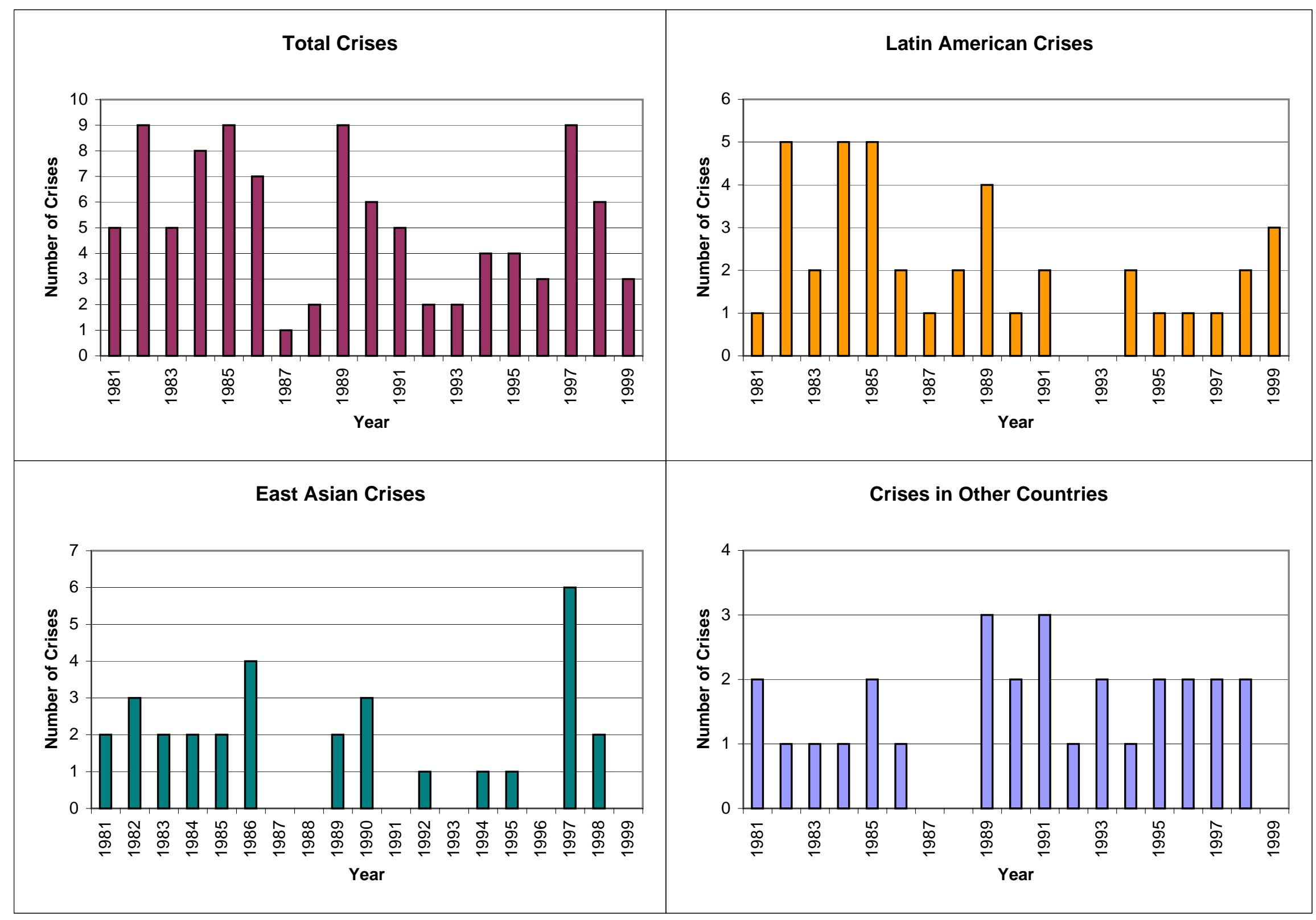

NB: Some crises were dropped due to a lack of explanatory variables in some countries in some years. Only crises used in estimating the probit model are included in this figure. 


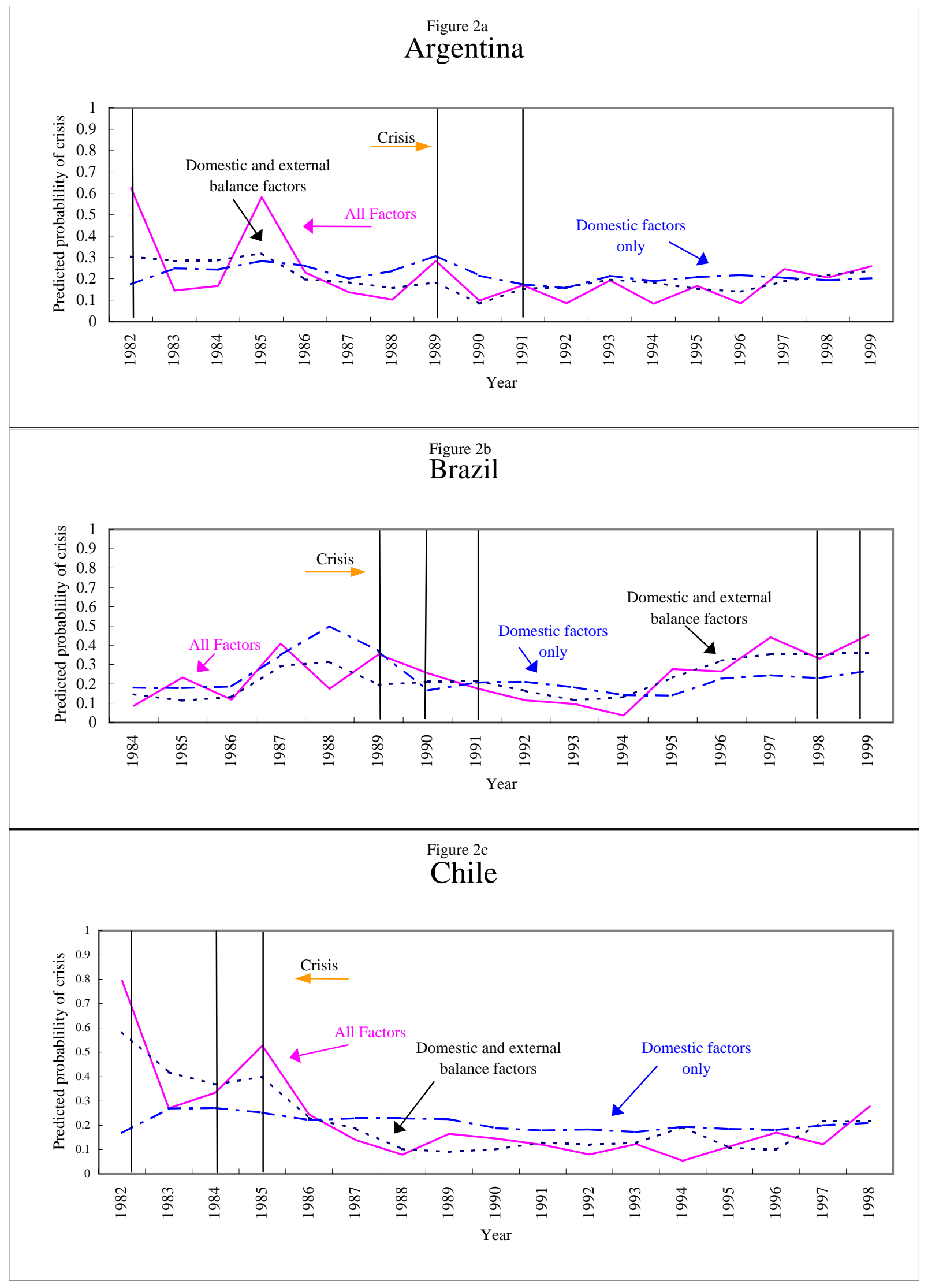




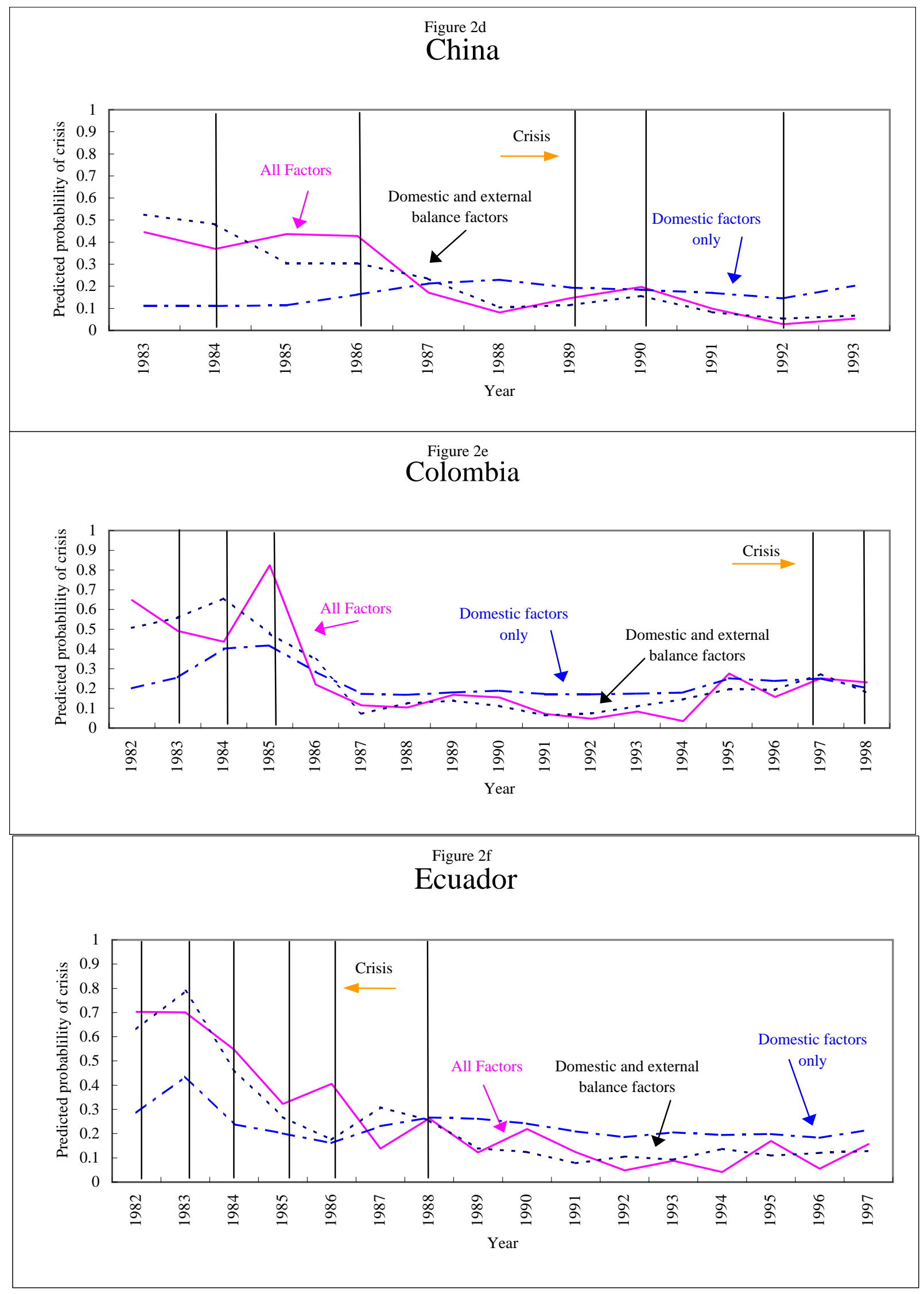




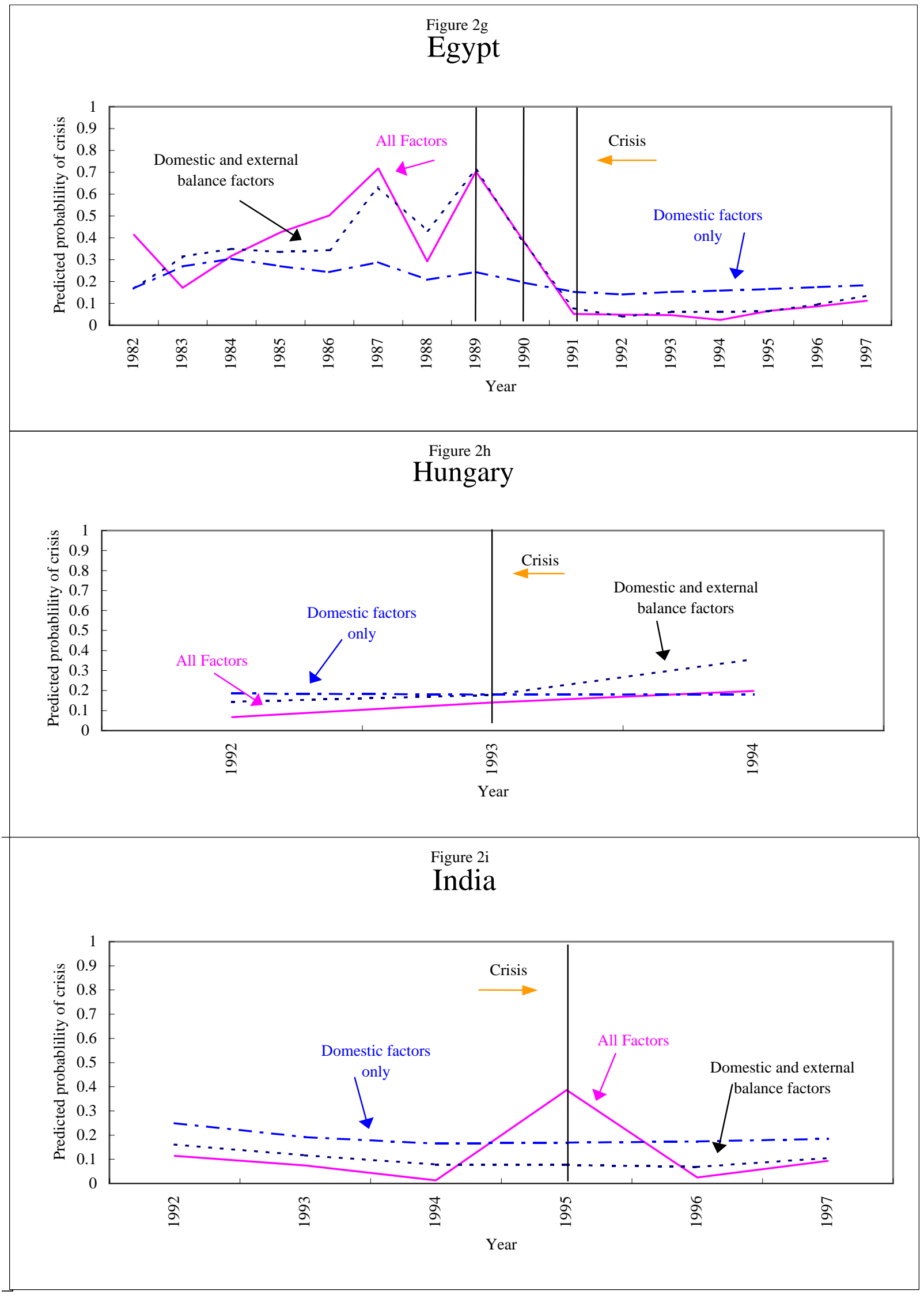




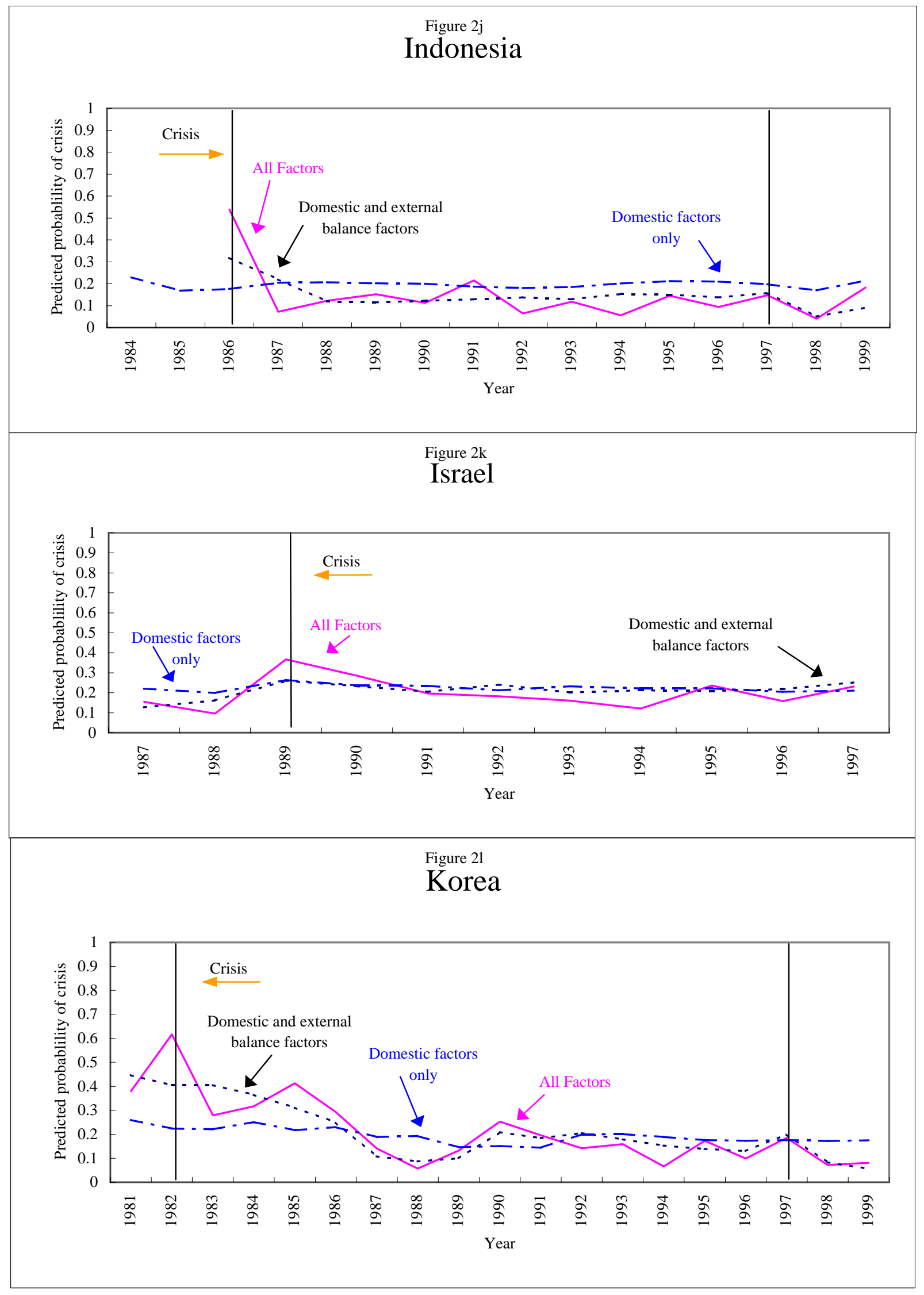




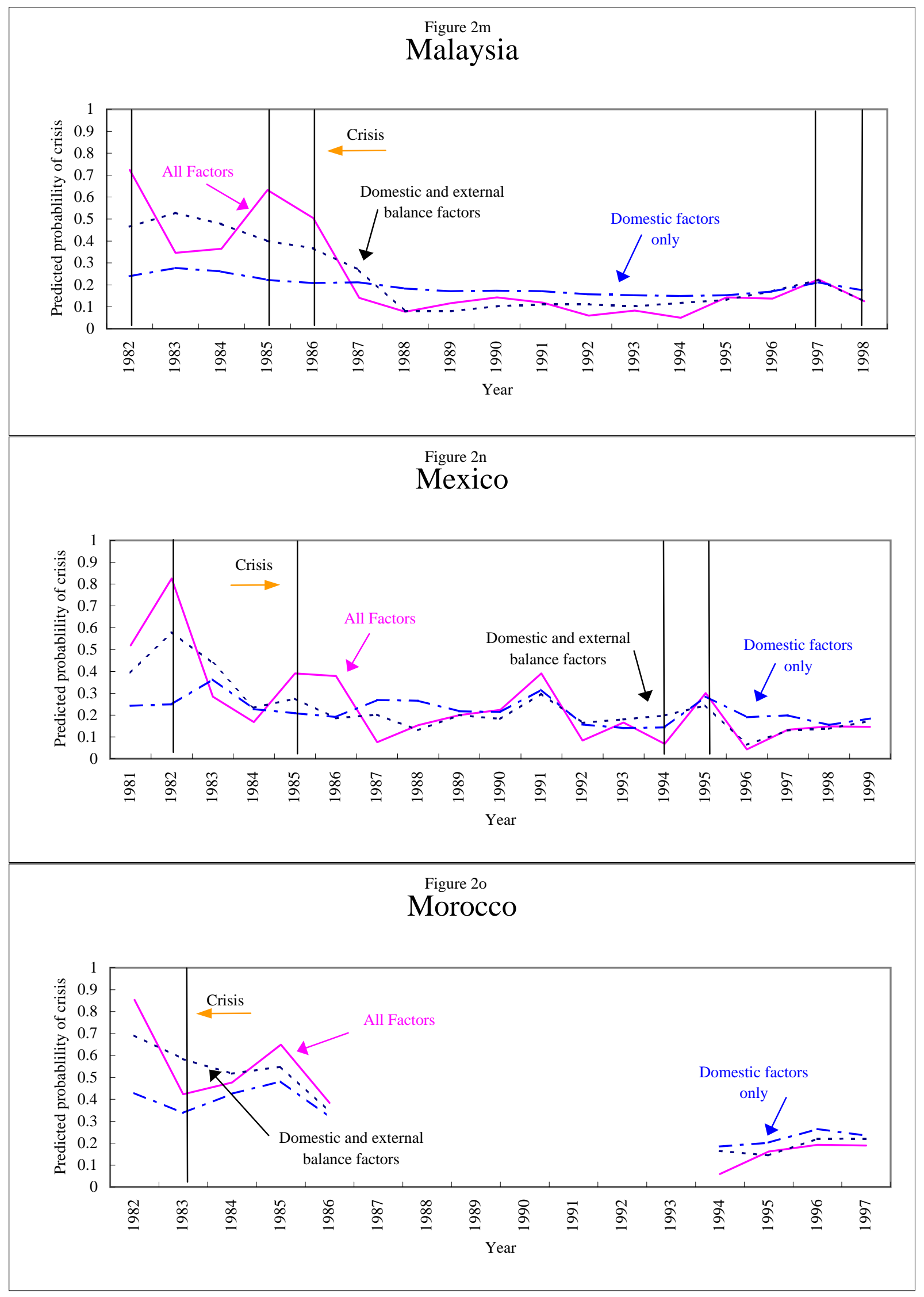




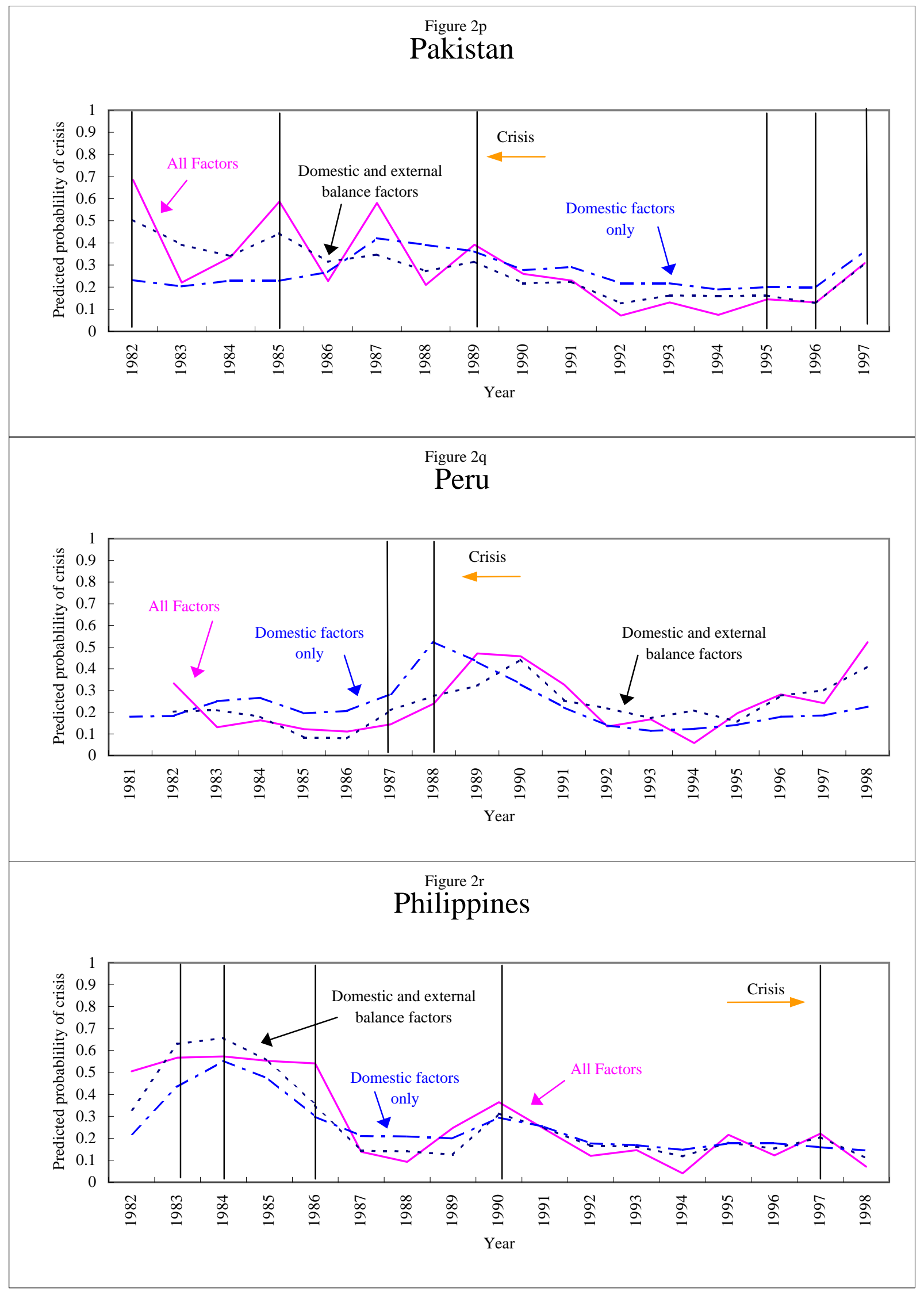




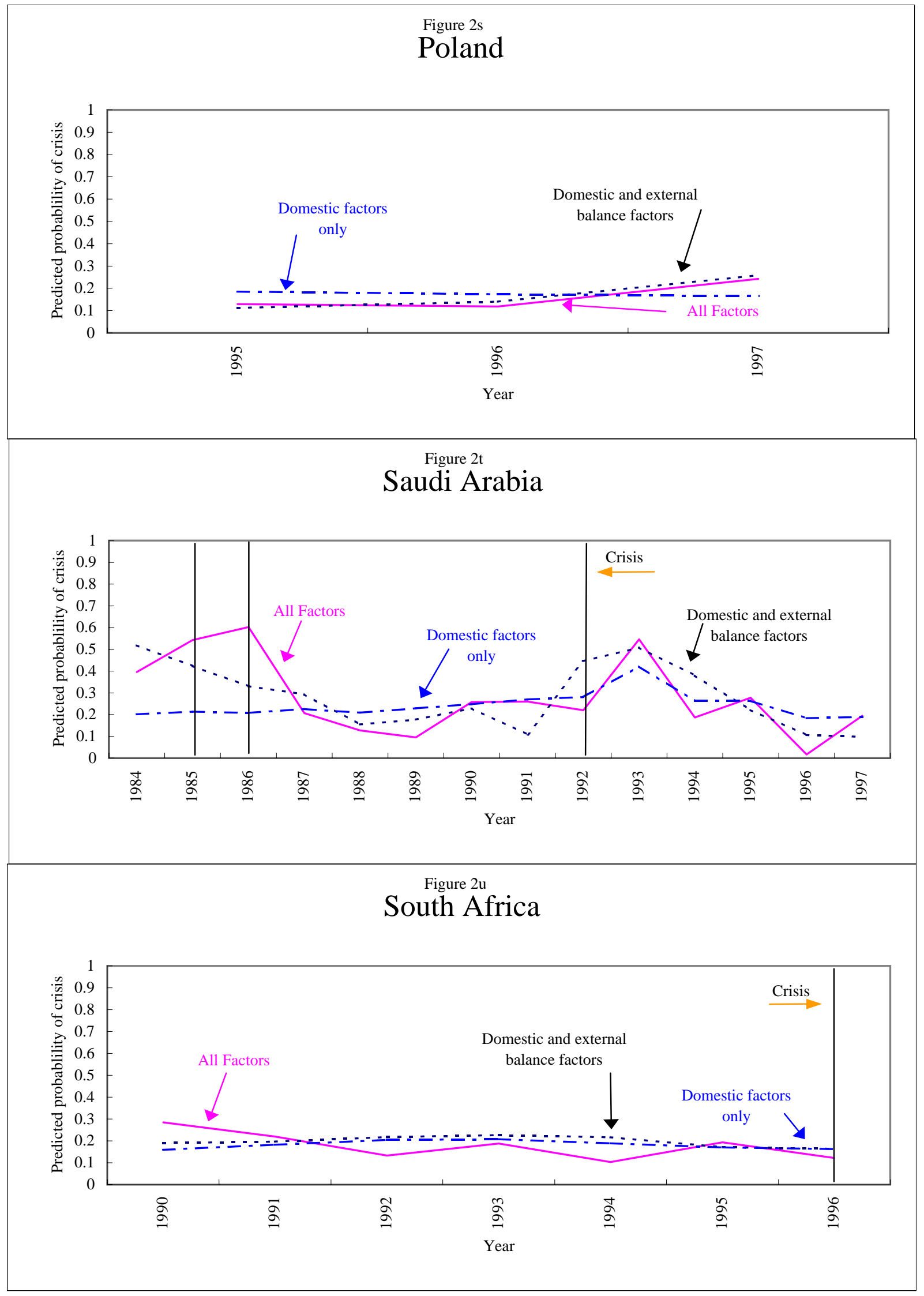




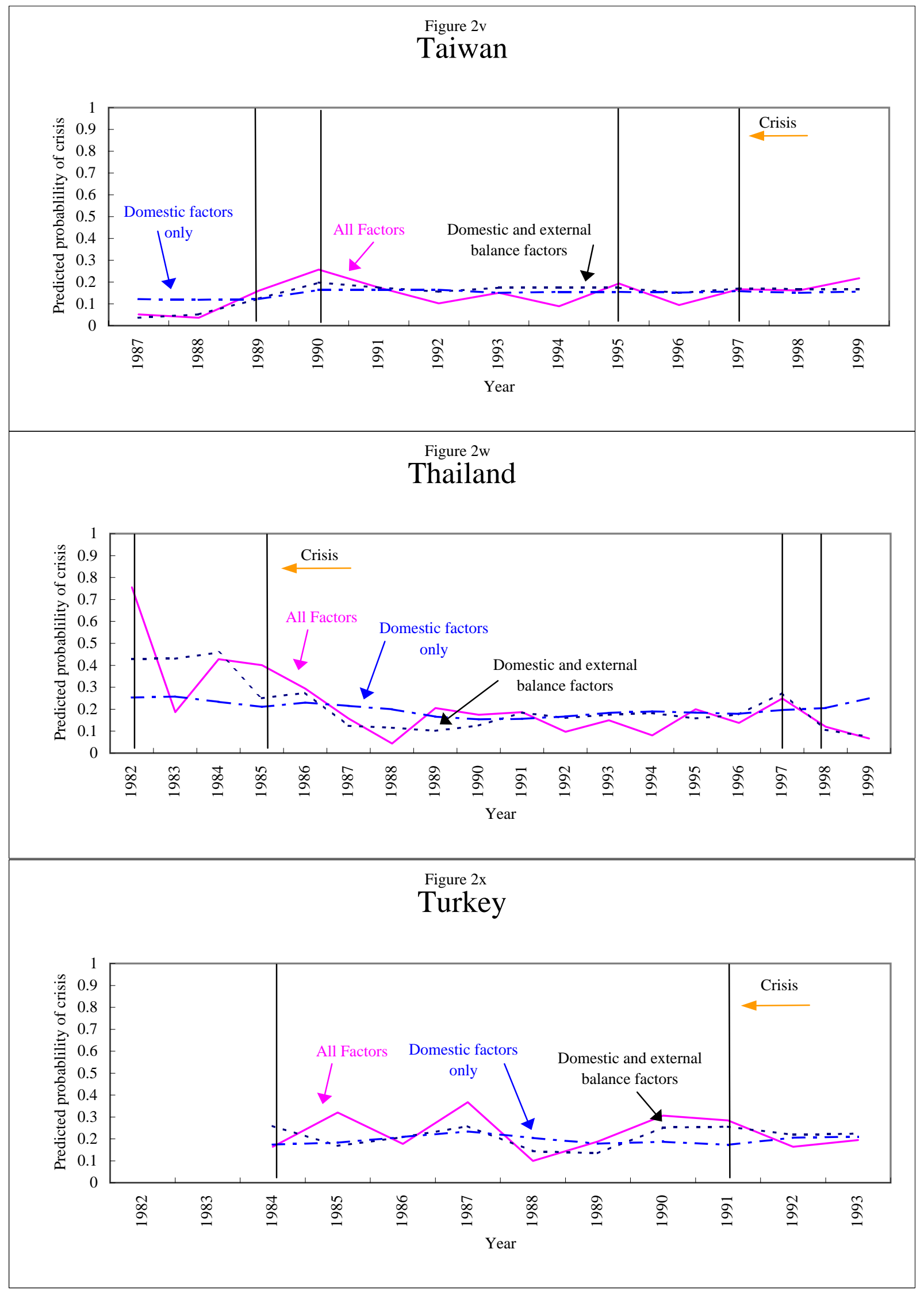




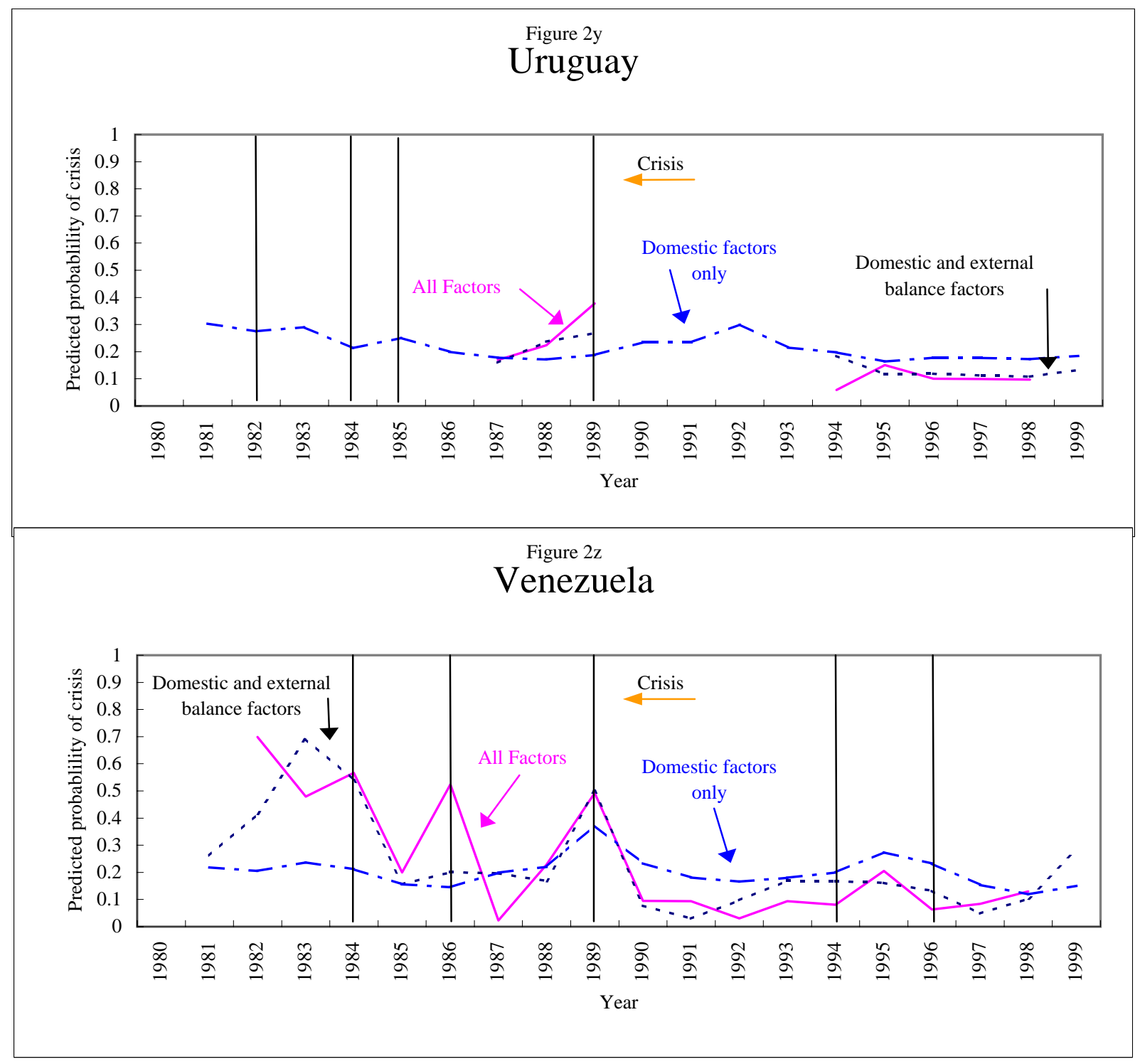


Appendix Table 1

\section{Calculation of Explanatory Variables}

(1) Growth of Real GDP

$$
\% \Delta \mathrm{GDP}_{\mathrm{t}}-\frac{\left(\% \Delta \mathrm{GDP}_{\mathrm{t}-1}+\% \Delta \mathrm{GDP}_{\mathrm{t}-2}+\% \Delta \mathrm{GDP}_{\mathrm{t}-3}\right)}{3}
$$

(2) Public Sector Deficit

$$
\frac{\text { Public Sector Deficit }}{\text { GDP }} \times 100
$$

(Note: “-“ denotes a surplus)

(3) Domestic Bank Loans

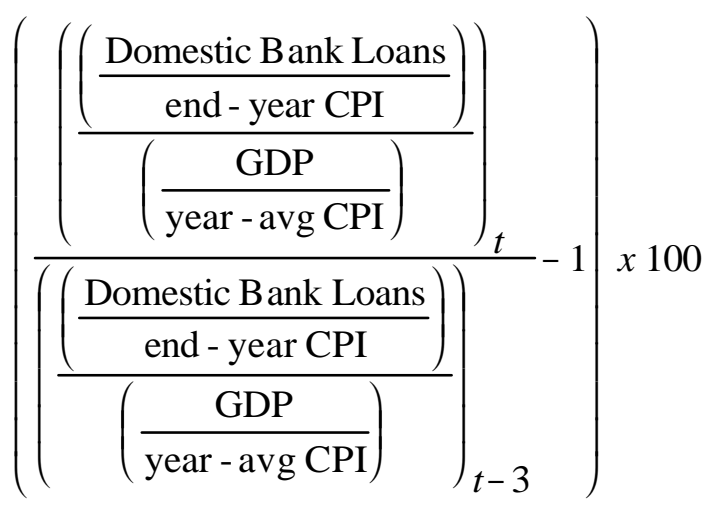

(4) Real Effective Exchange Rate

$$
\left(\left(\frac{\text { REER }_{\mathrm{t}}}{\left(\frac{\mathrm{REER}_{1980-1997}}{18}\right)}\right)-1\right) x 100
$$


(5) Exports

$$
\% \Delta \text { Exports }_{t}-\frac{\left(\% \Delta \text { Exports }_{t-1}+\% \Delta \text { Exports }_{t-2}+\% \Delta \text { Exports }_{t-3}\right)}{3}
$$

(6) Current Account

$$
\frac{\text { Current Account }}{\text { GDP }} \times 100
$$

(7) Foreign Direct Investment

$$
\frac{\text { Foreign Direct Investment }}{\text { GDP }} \times 100
$$

(8) M2 Money Supply

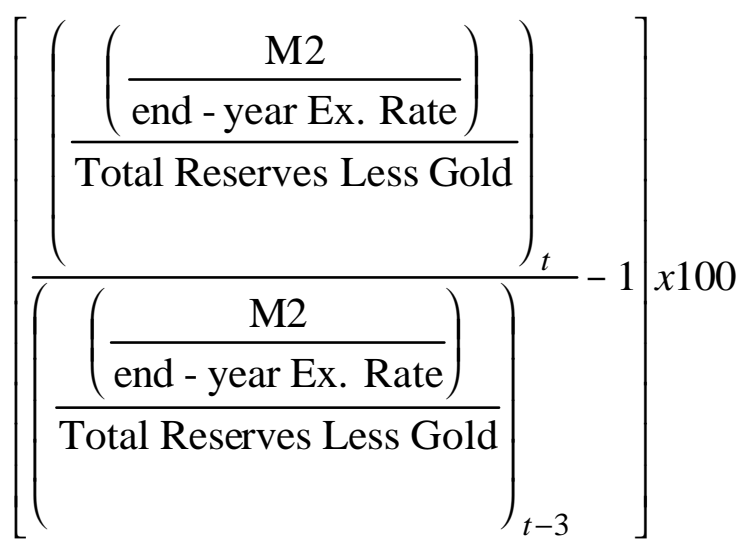

(9) Total External Debt

$$
\left(\frac{\text { Total External Debt }}{\text { Exports }}\right)-A v g\left(\frac{\text { Total External Debt }}{\text { Exports }}\right)_{1980-1999}
$$


(10) Short-term Debt

$$
\left(\frac{\text { Total Reserves Less Gold }}{\text { Short - term External Debt }}\right)-A v g\left(\frac{\text { Total Reserves Less Gold }}{\text { Short - term External Debt }}\right)_{1980-1999}
$$

(11) Terms of Trade

$$
\left[\left(\frac{\text { Terms of Trade }_{t}}{\text { Terms of Trade }_{t-1}}-1\right)-\left(\frac{\text { Terms of Trade }_{t-1}}{\text { Terms of Trade }_{t-2}}-1\right)\right] \times 100
$$

(12) U.S. Real Interest Rate

Average Annual U.S. 3-month Treasury Bill Rate - Annual Average CPI Inflation Rate

(13) Industrial Country GDP Growth

$$
\left[\left(\frac{\text { Industrial Country GDP }}{\text { Industrial Country GDP }_{\mathrm{t}-1}}-1\right)-\left(\frac{\text { Industrial Country } \mathrm{GDP}_{\mathrm{t}-1}}{\text { Industrial Country GDP }}-1\right)\right] \times 100
$$


Appendix Table 2

\section{Data Appendix}

Real Gross Domestic Product: International Financial Statistics (IFS), World Bank Development Indicators, Penn World Tables, International Monetary Fund (IMF), and national sources.

Public Sector Deficit: IFS, World Bank Development Indicators, IMF, Inter-American Development Bank (IADB), Penn World Tables and national sources.

Domestic Bank Loans: IFS, World Bank Development Indicators, IMF, Penn World Tables, Federal Reserve databases and national sources.

Real Effective Exchange Rate: JP Morgan, World Bank Development Indicators, IADB, IFS and Federal Reserve databases.

Exports: IFS, IMF, Federal Reserve databases and national sources.

Current Account: IFS, World Bank Development Indicators, Penn World Tables, IMF, World Bank, Federal Reserve databases and national sources.

Foreign Direct Investment: IFS, World Bank Development Indicators, IMF, Inter-American Development Bank (IADB), Penn World Tables and national sources.

M2 Money Supply: IFS, IMF and Federal Reserve databases.

Total External Debt: IMF, Bank for International Settlements, Organization for Economic Cooperation and Development, World Bank, Institute for International Finance, IFS, Federal Reserve databases and national sources.

Short-term Debt: IMF, Bank for International Settlements, Organization for Economic Cooperation and Development, World Bank, Institute for International Finance, IFS, Federal Reserve databases.

Terms of Trade: IADB, World Bank, UNCTAD, IFS, Federal Reserve databases and national sources.

U.S. Real Interest Rate: Federal Reserve databases.

Industrial Country GDP Growth: IFS and IMF. 